\title{
The Thomisidae and Philodromidae (Arachnida: Araneae) of the Galápagos Islands (Ecuador)
}

\author{
L. BAERT \\ Department of Entomology, Royal Belgian Institute of Natural Sciences, Vautierstraat 29, \\ B-1000, Brussels, Belgium. E-mail address: leon.baert@naturalsciences.be \\ urn:1sid:zoobank.org:author:52BD005E-6E8A-449C-91A3-5332B05D3702
}

\begin{abstract}
Two new species of Thomisidae are described (Mecaphesa reddelli sp. nov. and Tmarus galapagosensis sp. nov.). Of a third species, Mecaphesa inclusa (Banks, 1902), three colour variations are described. Tmarus specimens previously listed from the islands have always erroneously been called T. stolzmanni Keyserling, 1880. The Philodromidae are mentioned for the first time for the archipelago and are represented by two new species: Apollophanes fitzroyi sp. nov. and Apollophanes (?) lonesomegeorgei sp. nov.
\end{abstract}

Key words. new species, colour variation, Thomisidae, Philodromidae, island fauna.

Baert L. 2013. The Thomisidae and Philodromidae (Arachnida: Araneae) of the Galápagos Islands (Ecuador). European Journal of Taxonomy 43: 1-23. http://dx.doi.org/10.5852/ejt.2013.43

\section{Introduction}

The last updated species list published by Baert et al. (2008) was based on the collections made by the author and collaborators (Maelfait, Desender \& Hendrickx) between 1982 and 2002 and included specimens from all known collections housing spiders collected on the islands: American Museum of Natural History of New York (AMNH), the Natural History Museum of London (BMNH), Museum of Comparative Zoology of Cambridge (MCZ), Zoologisk Museum of Oslo (ZMUN), California Academy of Sciences (CAS), and collections made by: N. \& J. Leleup (RBINS: 1964-65), S. Jacquemart (RBINS 1974-75), H. Franz (Austria 1975), H. \& I. Schatz (Austria 1985-88), S. Peck (Canada 1985-96) and collections from the Charles Darwin Research Station (CDRS). One large collection was missing, the one made by W.G. Reeder during the years 1969-1980 and deposited at the Texas Memorial Museum of the University of Texas (TMM). He collected on many islands and used different collecting methods. I recently had the opportunity (late 2010 - early 2011) to study this rich material.

Two thomisid species were cited in this last updated species list (Baert et al. 2008): Mecaphesa inclusa (Banks, 1902) and Tmarus stolzmanni Keyserling, 1880, while no philodromids were mentioned.

The Tmarus species cited in several publications (see below) have erroneously been assigned to $T$. stolzmanni. The first two male specimens from the Galápagos archipelago were first collected during 
the Hopkins Stanford Galápagos Expedition of 1898-1899 by R.E. Snodgrass and identified by Banks (1902) as the species described as T. stolzmanni from Peru by Keyserling (1880). Though Banks (1902: p. 62, pl. II, fig. 5) stated that "the agreement of the male palp makes the identification certain", he gave a totally different drawing of the palp than that provided by Keyserling (1880: pp. 138-140, tab. III fig. 74). The tibial apophysis on Banks' drawing has a completely different configuration as the one of T. stolzmanni. It matches neither any published drawing of Tmarus palps nor the palps of the Tmarus species described without illustrations by Mello-Leitao (1929, 1941, 1942, 1943, 1944, 1949) and examined by me at the Museu Nacional of Rio de Janeiro. Apart from that important feature, the embolus of T. stolzmanni has an extra loop.

The type specimens of T. stolzmanni are lost or have been mislabelled after World War II bombardments and can thus not be compared with our specimens. Although quite a few juveniles are available in collections, adults of this species have rarely been caught in the past, probably due to its nocturnal mode of life (Lubin 1983). This author stated that the identification as T. stolzmanni remains tentative. A large number of specimens was caught by Prof. W. G. Reeder during his various 1969-1980 collecting trips which included night collecting on the different islands. Based on this rich material, it was finally concluded that the drawing made by Banks (1902: pl. II, fig. 5) does not match the palp of the specimens here examined and that the specimens of Galápagos thus belong to a separate new species, described in this paper.

Though the mention of this species in the first species list made by Roth \& Craig (1970) was based on the first Galápagos male specimens (citations by Banks 1902, 1930) and also on a female caught by N. Leleup in 1964, the female has never been described.

Reeder's material, collected mostly by sweeping and beating, revealed also a second new Mecaphesa species from Galápagos (Mecaphesa reddelli sp. nov.) which, according to the few records available, seems to have a broad northern distribution in the archipelago.

Two philodromid spider species can be added to the fauna of the islands. An Apollophanes species (Apollophanes fitzroyi sp. nov.) with a central archipelago distribution and a unique specimen from Isla Wolf. The latter specimen cannot be assigned to any described genus. It is incomplete, lacking the legs III and IV, but the uniqueness of the collection site warrants its description. Isla Wolf is a very small remote islet, far from the core of the archipelago in a north-westerly direction, difficult of access due to its steep cliffs and therefore rarely visited and sampled by scientists (area: $1.344 \mathrm{~km}^{2}$, elevation: 252 m, approximate distance from northernmost Isla Pinta: $c a .130 \mathrm{~km}$ ). In 1996 (11 and 13 May) Stewart Peck had the opportunity to visit the island and capture a few spiders, one of which was this unique philodromid specimen. In view of its uniqueness, it is considered reasonable to describe it as a new species and place it temporarily in Apollophanes.

\section{Material and methods}

The material used for this study comes principally from the collections at the RBINS, made in 1964 (N. \& J. Leleup) and between 1982 and 2009 (Baert, Maelfait and collaborators), the collections made by S. \& J. Peck and collaborators (1985-1996) deposited at the RBINS and the collections made by W.G. Reeder and collaborators (1969-1980) deposited at the TMM. All type specimens are deposited at the Royal Belgian Institute of Natural Sciences, Brussels.

The capture methods were hand catching, sweeping, beating and night collections. The colour given in the description is from specimens preserved in alcohol. 
All measurements were taken with a WILD M8 stereo microscope and are in mm. No scale bars are given in the figures or legends, but measurements (in $\mathrm{mm}$ ) of palp structures and epigyne are provided throughout the descriptions.

\section{Abbreviations:}

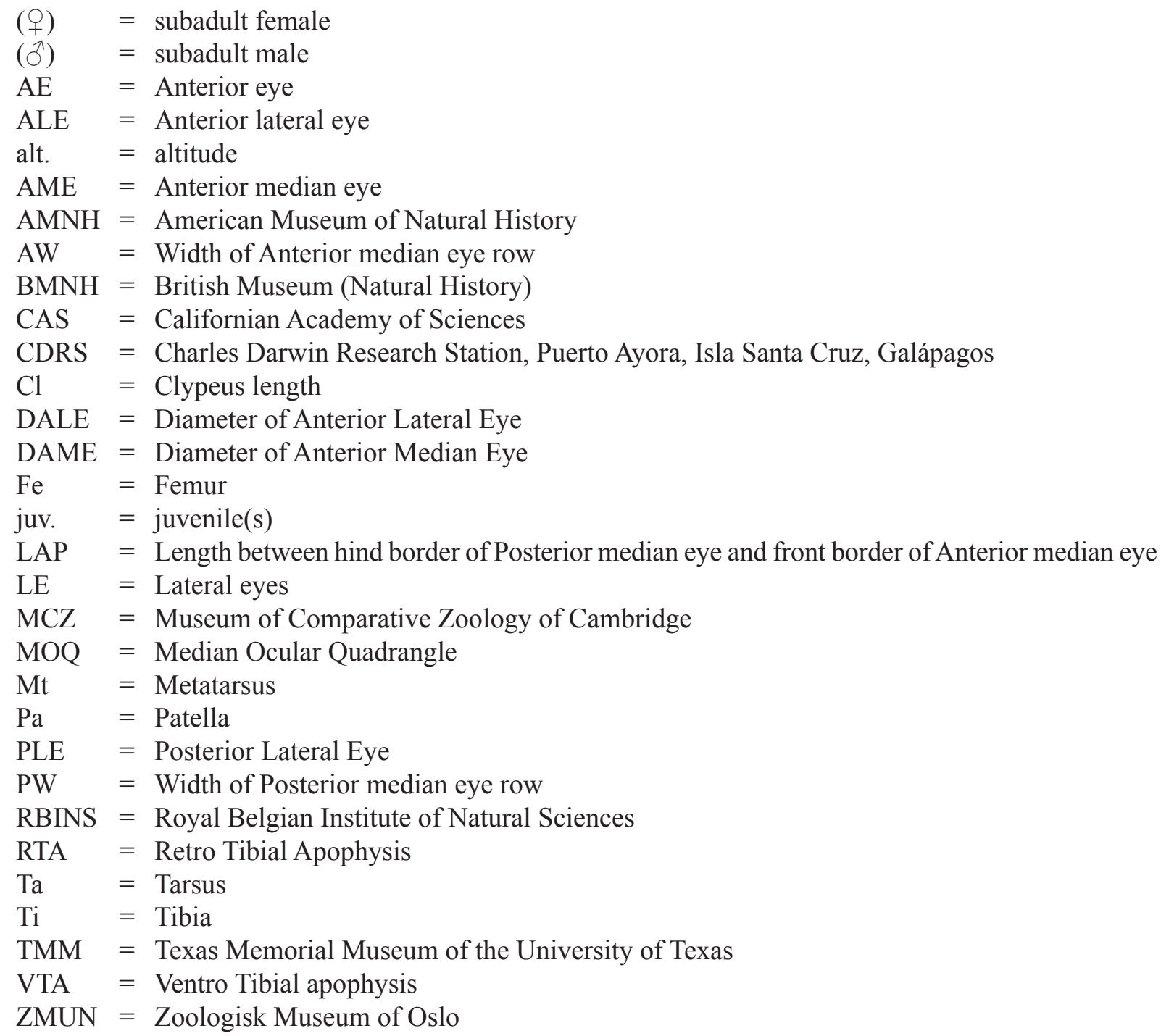

\section{Results}

\section{Taxonomy}

Class Arachnida Cuvier, 1812

Order Araneae Clerck, 1757

Family Thomisidae Sundevall, 1833

Genus Mecaphesa Simon, 1900

Mecaphesa inclusa (Banks, 1902)

Figs 1A-C, 3A, 9A-D

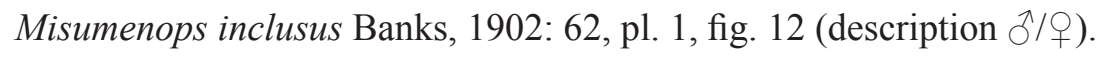


Misumenops inclusus - Roth \& Craig 1970: 119. — Baert \& Maelfait 1986: 119, map 25. — Baert, Maelfait \& Desender 1988: 50, 53. — Baert, Maelfait \& Desender 1989: 21.

Mecaphesa inclusa - Lehtinen 1993: 587. — Baert \& Maelfait 2000: 244. — Baert, Maelfait, Hendrickx \& Desender 2008: 67, map 149.

\section{Material examined}

All the material ever sampled has been screened (see other material examined). The localities given in this section are those of the voucher specimens used for the description of the colour variety.

Locality of male voucher specimen A: Meteorological Station of CDRS, 2 m alt., 15 Feb. 1982 (leg. L. Baert \& J.-P. Maelfait); female voucher specimen A: Isla Isabela, Volcán Alcedo, 600 m alt., 2 Apr. 1986 (leg. L. Baert, J.-P. Maelfait \& K. Desender).

Locality of male voucher specimen B: Isla Isabela, Volcán Alcedo, Zanthoxylum-Scalesia savanna, 790 m alt., 14 May 1980 (leg. W.G. Reeder).

Locality of male and female voucher specimens C: Isla Isabela, Volcán Alcedo, Pega Pega Camp, 600 m alt., Scalesia, 24-25 May 1980 (leg. D. Green).

The voucher specimens described here are deposited at the RBINS at Brussels.

\section{Other material examined}

ISLA FERNANDINA: ^̋, between Cabo Hammond and Bursera Hills, 70 m alt., 26 Apr. 1975; ô, o, 4 juv., west vegetation strip, $30 \mathrm{~m}$ alt., 10 Aug. 1977; $2 \curvearrowright \AA$, $q$, numerous juv., west vegetation strip, flush

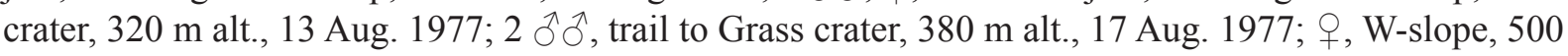
m alt., 17 Aug. 1977, leg. W.G. Reeder.

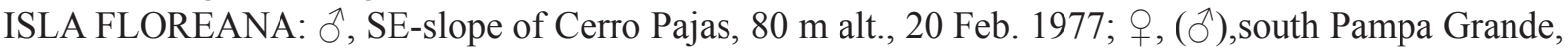
$270 \mathrm{~m}$ alt., 22 Feb. 1977, leg. W.G. Reeder.

ISLA GENOVESA: Oૈ, Barranco at Bahía Darwin, 20 m alt., 10-27 Mar. 1992.

ISLA ISABELA: VOLCÁN SIERRA NEGRA: $q$, east of crater floor, 925 m alt., 19 Feb. 1986, leg. L.

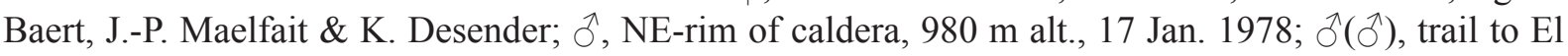
Papal above Sto Tómas, 480 m alt., 19 Jan. 1978; đૂ, (ठ), 4 (우), Zona Velasco Ibarra (near Scalesia quadrat), $760 \mathrm{~m}$ alt., 2 Jan. 1978, leg. W.G. Reeder. VOLCÁN ALCEDO: đ 2 Apr. 1986, leg. L. Baert, J.-P. Maelfait \& K. Desender; 4 đ̃, E-slope, Bursera camp, 340 m alt., 18-19

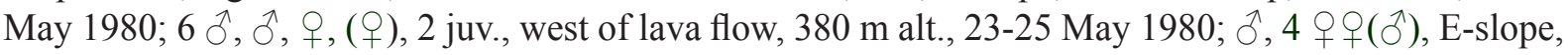

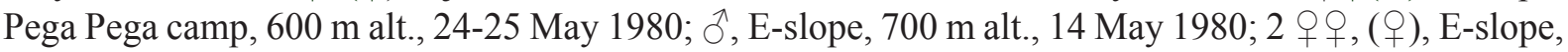

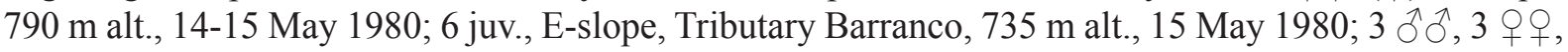
east of lava flow, $600 \mathrm{~m}$ alt., 24 May 1980; $3 \hat{\partial}, 3$, $1000 \mathrm{~m}$ alt., 24-25 May 1980; $\widehat{\jmath}$, rim, 1130-1160 m, 24 May 1980, leg. W.G. Reeder. VOLCÁN DARWIN: juv., along transect to the top, $800 \mathrm{~m}$ alt.,

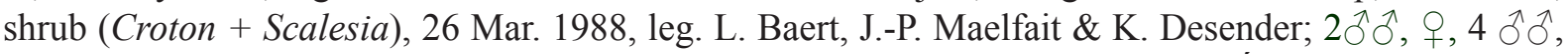
numerous juv., Beagle crater, 40-50 m alt., 2 May 1980, leg. W.G. Reeder. VOLCÁN ECUADOR: đ̂, 2 , Cabo Berkeley, 20-90 m alt., 8 Aug. 1977, leg. W.G. Reeder.

ISLA MARCHENA: ${ }^{\lambda}$,, , Kipouka, 150 m alt., 29 Jan. 1977; $\curvearrowright$, SW-slope, Barranco, trail to fumaroles, $60 \mathrm{~m}$ alt., 30 Jan. 1977; đ', S-slope, near fumaroles ridge, $190 \mathrm{~m}$ alt., 26 Jan. 1977, leg. W.G. Reeder.

ISLA PINTA: †, May 1964 (TMM); + , S-slope, 400 m alt., 19 Jul. 1977, leg. W.G. Reeder; 2 $ぇ$, transition zone, $200 \mathrm{~m}$ alt., 14 Mar. 1992, leg. S. \& J. Peck.

ISLA PINZON: 2 우, crater camp ridge summit, 320 m alt., 6 Feb. 1979, leg. W.G. Reeder.

ISLA RABIDA: ${ }^{7}$, ㅇ, N-slope, 180 m alt., 29 Sep. 1975; ㅇ, N-slope, 270 m alt., 29 Sep. 1975, leg. W.G. Reeder.

ISLA SANTIAGO: §̊, Aguacate camp, 550 m alt., 13 Apr. 1992, leg. S. \& J. Peck. 
BAERT L., The Thomisidae and Philodromidae of the Galápagos Islands

ISLA SANTA CRUZ: + , Playa Tortuga, 2 m alt., 8 Jun. 1975, leg. H. Franz; + , 3 juv., trail from Caseta Tortuga towards the coast, $130 \mathrm{~m}$ alt., 18 Aug. 1970, leg. S Riechert; 4 juv., along old trail to Bellavista,

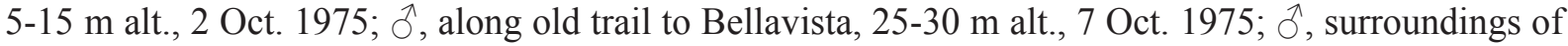
the CDRS, $10 \mathrm{~m}$ alt., $18 \mathrm{Feb}$ 1979; +, Puerto Ayora, $20 \mathrm{~m}$ alt., 26 Apr. 1980: $0,500 \mathrm{~m}$ NE of Cerro Puntudo pass, 700-720 m alt.; đ̂, along old trail to Bellavista, 80-100 m alt., 4 May 1980; 0 , 7 May 1980, leg. W.G. Reeder; juv., surroundings of CDRS, 5 m alt., 23 Mar. 1985, leg. H. \& I. Schatz; ( $\left.{ }^{\Uparrow}\right)$, surroundings of CDRS, 5 m alt., 19 Jan. 1989; 3 juv., 7 km N of Santa Rosa, $550 \mathrm{~m}$ alt., 1 Jun. 1991, leg. S. \& J. Peck; + , Cerro Messa summit, 22 Jan. 2010, leg. F. Hendrickx; + , surroundings of the CDRS, 21 Apr. 1981; juv., Puerto Ayora, in building, 5 Nov. 1991 (CDRS collections).

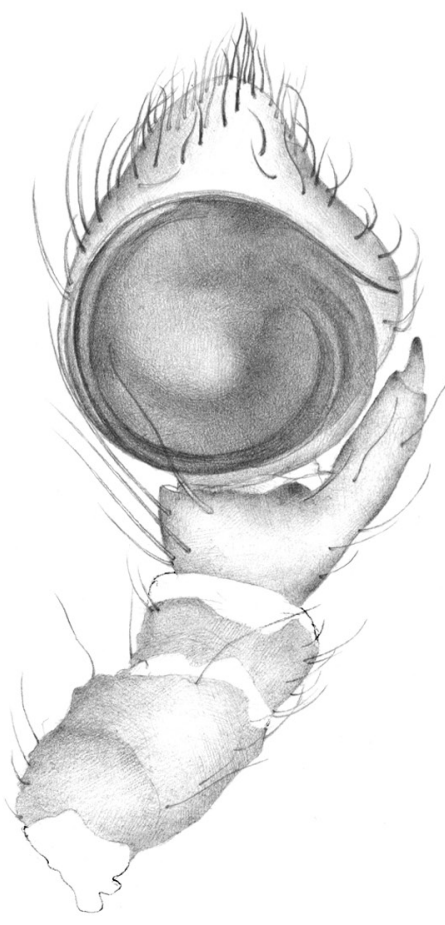

A
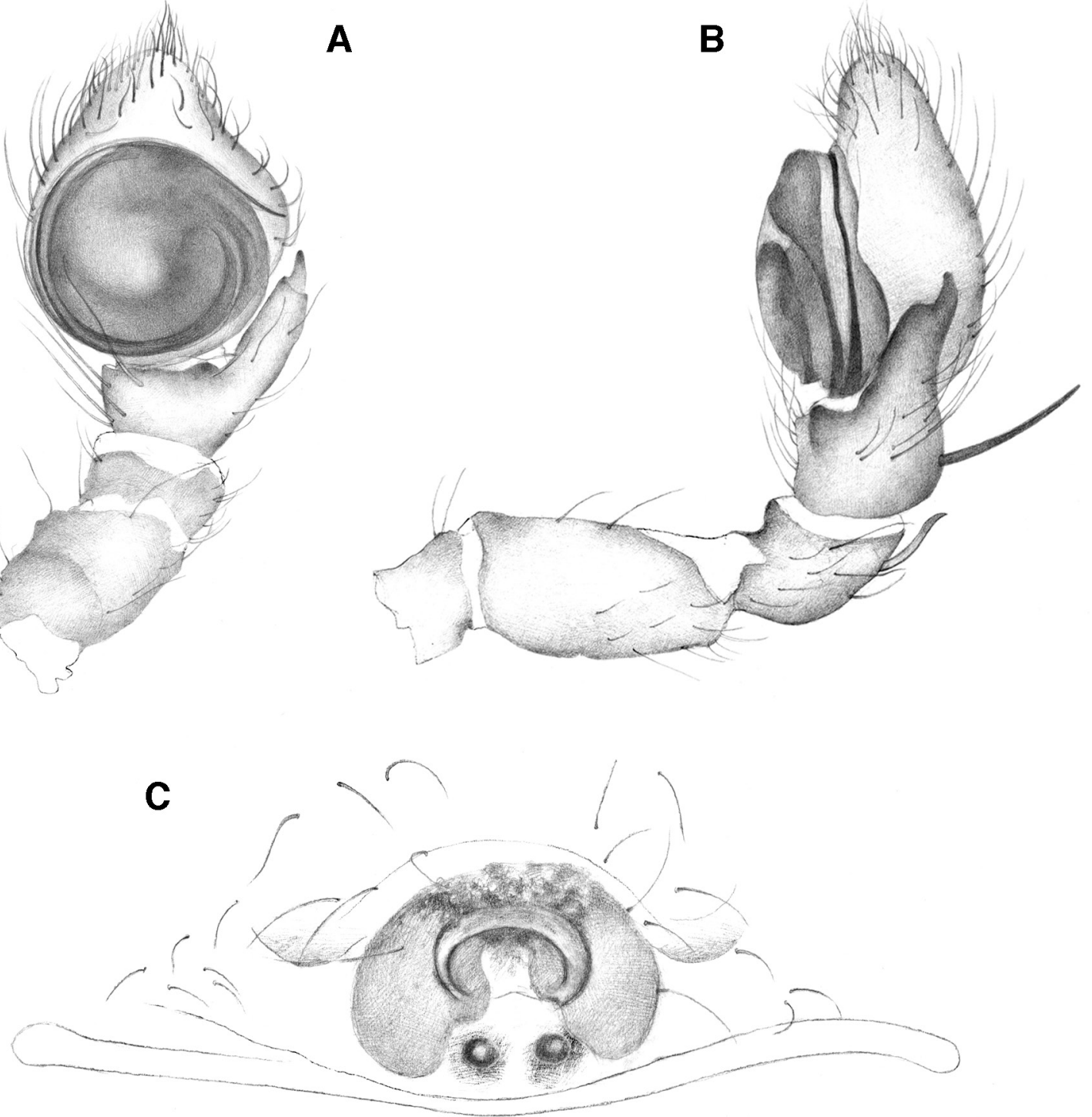

Fig. 1. Mecaphesa inclusa (Banks, 1902). A. đ̊ palp, ventral view. B. đ palp, retrolateral view. C. epigyne. 
Material is deposited either at the RBINS (collections made by L. Baert et al., F. Hendrickx, S. \& J. Peck and H. Franz) or the TMM (collections made by W.G. Reeder, S. Riechert).

\section{Cited in the literature}

ISLA ISABELA, VOLCÁN DARWIN: Tagus Cove, ô, $q$ (Banks 1902).

\section{Short general description of the species}

Prosoma. With few dispersed long and short setae; lateral prosoma borders provided with very short setae, anterior clypeal border with long setae; clypeus with a proximal central long seta; ocular area with a long seta just above AE; chelicerae with one proximal median long seta; coxae with dorsal setae.

Opisthosoma. Few dispersed long and short setae (only short setae in female).

Legs. Pa III \& IV without dorsal spines.

PALP. Tibia of male palp with 1 dorsal and 3 prolateral spines; RTA with hooked tip; VTA inconspicuous. Embolus with retrolateral origin, slowly curled at tip. Cymbium without tutaculum or tutacular groove.

EPIGYNE. Atrium with sclerified anterior and lateral borders and raised hood, small spermathecal organs conspicuous, close to epigynal fold (Fig. 2C); vulva with irregularly shaped spermathecae with mesal spermathecal organs, thick curled copulatory tubes (Fig. 3A).

This species shows variation in colour among males and between males and females. There is, however, no specific distribution pattern of the three kinds of colour patterns. A description of a male and female voucher specimen of each encountered common colour variety is given here.

\section{Description of voucher specimens}

Male A (Fig. 9A)

Total LENGTH. 2.27; prosoma length: 1.09, width: 1.17, height: 0.49 .

CoLour. Prosoma: chestnut brown speckled with irregular yellowish spots; clypeus, ocular area and dorsal thoracic area paler brown; chelicerae brown suffused with black; labium, endites and sternum blackish brown with small irregular light patches. Legs I \& II: Fe, Pa and Ti brown; Mt brown with lighter proximal half; Ta yellowish with light brown distal half. Leg III: Fe yellow with brown distal tip; Pa dark; Ti, Mt and Ta yellowish with dark proximal part. Leg IV: Fe yellow with brown distal tip; Pa and Ti dark; Mt and Ta yellowish with dark proximal part. Opisthosoma: with shiny sclerotized dorsum with a pattern of black, brown and light chevron-like patches; sides black; venter greyish; spinnerets light.

Eyes. MOQ: $\mathrm{AW}=0.74 \mathrm{PW}, \mathrm{AW}=0.92 \mathrm{LAP}, \mathrm{Cl}=3$ DAME.

Legs. Measurements: I (5.10): Fe 1.55, Pa 0.60, Ti 1.26, Mt 1.07, Ta 0.62; II (4.89): Fe 1.51, Pa 0.60, Ti 1.15, Mt 1.05, Ta 0.58; III (2.12): Fe 0.66, Pa 0.33, Ti 0.43, Mt 0.37, Ta 0.33; IV (2.14): Fe 0.68, Pa 0.31 , Ti 0.43 , Mt 0.39, Ta 0.33. Length of cymbium: 0.21 .

\section{Female A}

Total Length. 3.33; prosoma length: 1.46, width: 1.44, height: 0.59 .

CoLour. Prosoma: orange speckled with brown irregular stains; labium yellow brown; endites and sternum yellowish strongly suffused with black. Legs I \& II: orange brown dorsally, ventrally strongly 
suffused with (almost) black; Legs III \& IV: Fe, Mt \& Ta whitish with orange brown distal tip, Pa \& Ti orange brown ventrally suffused with black. Opisthosoma: dorsum yellowish strongly suffused with black, venter whitish with central part greyish; spinnerets orange.

EYES. MOQ: $\mathrm{AW}=0.84 \mathrm{PW}, \mathrm{AW}=1.00 \mathrm{LAP}, \mathrm{Cl}=0.1 \mathrm{DAME}$.

Legs. Measurements: I (5.42): Fe 1.71, Pa 0.78, Ti 1.24, Mt 1.03, Ta 0.66; II (5.19): Fe 1.63, Pa 0.76, Ti 1.17, Mt 1.01, Ta 0.62; III (2.82): Fe 0.87, Pa 0.49, Ti 0.64, Mt 0.45, Ta 0.37; IV (2.98): Fe 0.87, Pa 0.47, Ti 0.60, Mt 0.56, Ta 0.39. Spination: ventral rows of strong spines: Ti I: 5, Mt I: 4, Ti II: 3, Mt II: 4.

Male B (Fig. 9B)

Total Length. 2.55; prosoma length: 1.13, width: 1.24, height: 0.49 .

Colour. Prosoma: orange with two parallel longitudinal dark bands flanked by a row of 4 long setae along inner border; eye region white surrounded; clypeus white; chelicerae, endites and sternum orange. Legs I \& II: Fe, Pa: orange; Ti, Mt: orange with dark distal part (1/3th); Ta: orange slightly suffused with black. Legs III \& IV: light orange. Pedipalp: light orange. Opisthosoma: White dorsum, shiny with 4 dark chevrons; sides blackish, venter whitish.

EYEs. MOQ: $\mathrm{AW}=0.73 \mathrm{PW}, \mathrm{AW}=0.89 \mathrm{LAP}, \mathrm{Cl}=2.7 \mathrm{DAME}$.

Legs. Measurements: I (6.82): Fe 2.06, Pa 0.70, Ti 1.75, Mt 1.55, Ta 0.76; II (5.65): Fe 1.73, Pa 0.54, Ti 1.42, Mt 1.26, Ta 0.70; III (3.26): Fe 1.04, Pa 0.39, Ti 0.76, Mt 0.64, Ta 0.43; IV (3.25): Fe 1.03, Pa 0.39 , Ti 0.72 , Mt 0.68 , Ta 0.43 .

\section{Male C (Fig 9C)}

Total Length. 2.39; prosoma length: 1.07, width: 1.17, height: 0.49 .

Colour. Prosoma: brown with dorsal V-mark consisting of speckled white spots, sides speckled with few small white spots; chelicerae and sternum brown speckled with small white spots; endites brown. Legs I \& II: brown with Fe, Pa \& Ti speckled with few small white spots. Leg III: Fe yellowish with dark distal end, Pa dark, Ti-Ta yellowish. Leg IV: Fe yellowish with dark distal end, Pa \& Ti dark, Mt \& Ta yellowish. Pedipalp: brown, Ti with dark proximal and distal end. Opisthosoma: shiny brown speckled with small white spots, venter beige.

EYes. MOQ: $\mathrm{AW}=0.79 \mathrm{PW}, \mathrm{AW}=0.96 \mathrm{LAP}, \mathrm{Cl}=3.5 \mathrm{DAME}$.

Legs. Measurements: I (4.96): Fe 1.55, Pa 0.62, Ti 1.22, Mt 1.07, Ta 0.60; II (4.80): Fe 1.51, Pa 0.60, Ti 1.17, Mt 1.02, Ta 0.50; III (2.23): Fe 0.68, Pa 0.36, Ti 0.45, Mt 0.41, Ta 0.33; IV (2.22): Fe 0.70, Pa 0.33 , Ti 0.47, Mt 0.41 , Ta 0.31 .

Female C (Fig. 9D)

Total Length. 4.27; prosoma length: 1.69, width: 1.75, height: 0.70 .

Colour. As in male.

EYES. MOQ: $\mathrm{AW}=0.809 \mathrm{PW}, \mathrm{AW}=1.00 \mathrm{LAP}, \mathrm{Cl}=2.6 \mathrm{DAME}$.

Legs. Measurements: I (6.36): Fe 1.99, Pa 0.97, Ti 1.44, Mt 1.20, Ta 0.76; II (6.08): Fe 1.90, Pa 0.93, Ti 1.38, Mt 1.17, Ta 0.70; III (2.99): Fe 0.93, Pa 0.54, Ti 0.60, Mt 0.54, Ta 0.38; IV (3.32): Fe 1.09, Pa 0.50, Ti 0.70, Mt 0.62, Ta 0.41. Spination: ventral rows of strong spines: Ti I : 5, Mt I: 4, Ti II \& Mt II: 4. 


\section{Distribution}

Occurs throughout the whole archipelago except for the south-easternmost islands of Santa Fé, Española and San Cristóbal. This species has a wide distribution on the islands from the low arid zone up to the summit of the islands with the highest catch on the summit of Volcán Alcedo at an altitude of $c a .1160 \mathrm{~m}$.

\section{Mecaphesa reddelli sp. nov. urn:lsid:zoobank.org:act:A1438F2A-8FE2-4BD9-822C-3667F88CED3B}

Figs 2A-C, 3B, 9E-F

\section{Diagnosis}

Males of $M$. reddelli can be recognized by the palpal tibia bearing one dorsal and four pro-lateral spines, RTA with smooth slightly curved tip (strongly hooked in $M$. inclusa), a short curved VTA (inconspicuous in $M$. inclusa). Females differ from those of other species by its pentagonal shaped epigyne cavity with lobate anterior borders (cavity oval shaped in M. inclusa).

\section{Etymology}

The species is named after James Reddell of the Texas Memorial Museum who gave me the opportunity to study the spiders caught by W. G. Reeder during his various collecting trips between 1975 and 1980 .

\section{Type material}

\section{Holotype}

o, ISLA SANTA CRUZ, Cerro Colorado, $20 \mathrm{~m}$ alt., from Scalesia litter at 200-300 m SW of base of Cerro, 13 Mar. 1975, leg. W.G. Reeder.

\section{Allotype}

+ , ISLA ISABELA, Volcán Alcedo, Pega Pega Camp, $783 \mathrm{~m}$ alt., from large Waltheria bush in the Scalesia savannah, 13 May 1980, leg. W.G. Reeder.

\section{Paratypes}

ISLA SANTA CRUZ: 1 ð, Cerro Colorado, 10 m alt., 11 Mar. 1975, leg. W.G. Reeder.

ISLA ISABELA: 1 \%, Volcán Darwin, outside slope Beagle crater, 40-50 m alt., beating Acacia rorudiana, 22 May 1980, leg. W.G. Reeder.

ISLA GENOVESA: 1 \%, 1 juv., 500 m from SE-crater rim, 50 m alt., 25 Oct. 1975, leg. W.G. Reeder. ISLA PINTA: 1 q, pampa, 400 m alt., 18 Jul. 1977, leg. W.G. Reeder.

\section{Description}

\section{Male holotype}

Total LENGTH. 3.45; prosoma length: 1.53 , width: 1.61 , height: 0.49 ; chelicerae: 0.54 ; opisthosoma length: 2.06 , width: 1.40 , height: 1.07 .

Prosoma. With long setae arranged in three rows, one just behind posterior eyes and 2 rear oblique rows (Fig. 9G); lateral borders of entire prosoma provided with very short setae; clypeus with a row of 7 setae; anterior and posterior lateral eyes on tubercle, PE directed backwards; chelicerae with a proximal median long seta; coxae with dorsal setae.

Opisthosoma. With many long setae.

CoLour. Prosoma: orange brown with triangular lighter area behind the posterior eyes, eye region whitish; chelicerae, labium, endites and sternum orange brown. Legs I \& II: yellow brown; Ti, Mt and 
Ta with dark brown distal end (Mt for 2/3th brown). Legs III \& IV: yellow. Opisthosoma: creamy with white stains and irregular rows of black stains (6 are very obvious in caudal part) on dorsum (Fig. 9F).

Eyes. MOQ: $\mathrm{AW}=0.85 \mathrm{PW}, \mathrm{AW}=0.89 \mathrm{LAP}, \mathrm{Cl}=3.4 \mathrm{DAME}, \mathrm{DALE}=0.16$.

Legs. Measurements: I (9.89): Fe 2.75, Pa 0.94, Ti 2.16, Mt 1.96, Ta 1.02; II (8.43): Fe 2.59, Pa 0.94, Ti 2.08, Mt 1.84, Ta 0.98; III (3.97): Fe 1.24, Pa 0.52, Ti 0.89, Mt 0.76, Ta 0.56; IV (4.04): Fe 1.26, Pa 0.49, Ti 0.93, Mt 0.80, Ta 0.56. Spination: Fe I: d2pl3, Fe II: d2-3, Fe III: d2, Fe IV: d2; Pa I-II: d0, P III-IV: d2; Ti I-IV: d2. Pa III \& IV with 2 dorsal spines.

PaLp. (Fig. 2A, B) Tibia with 1 dorsal and 4 pro-lateral spines; RTA with smooth slightly curved tip; short curved VTA. Embolus with retro-lateral origin, slightly curled at tip. Cymbium without tutaculum or tutacular groove; 2 pro-lateral spines. Length of cymbium: 0.52 .
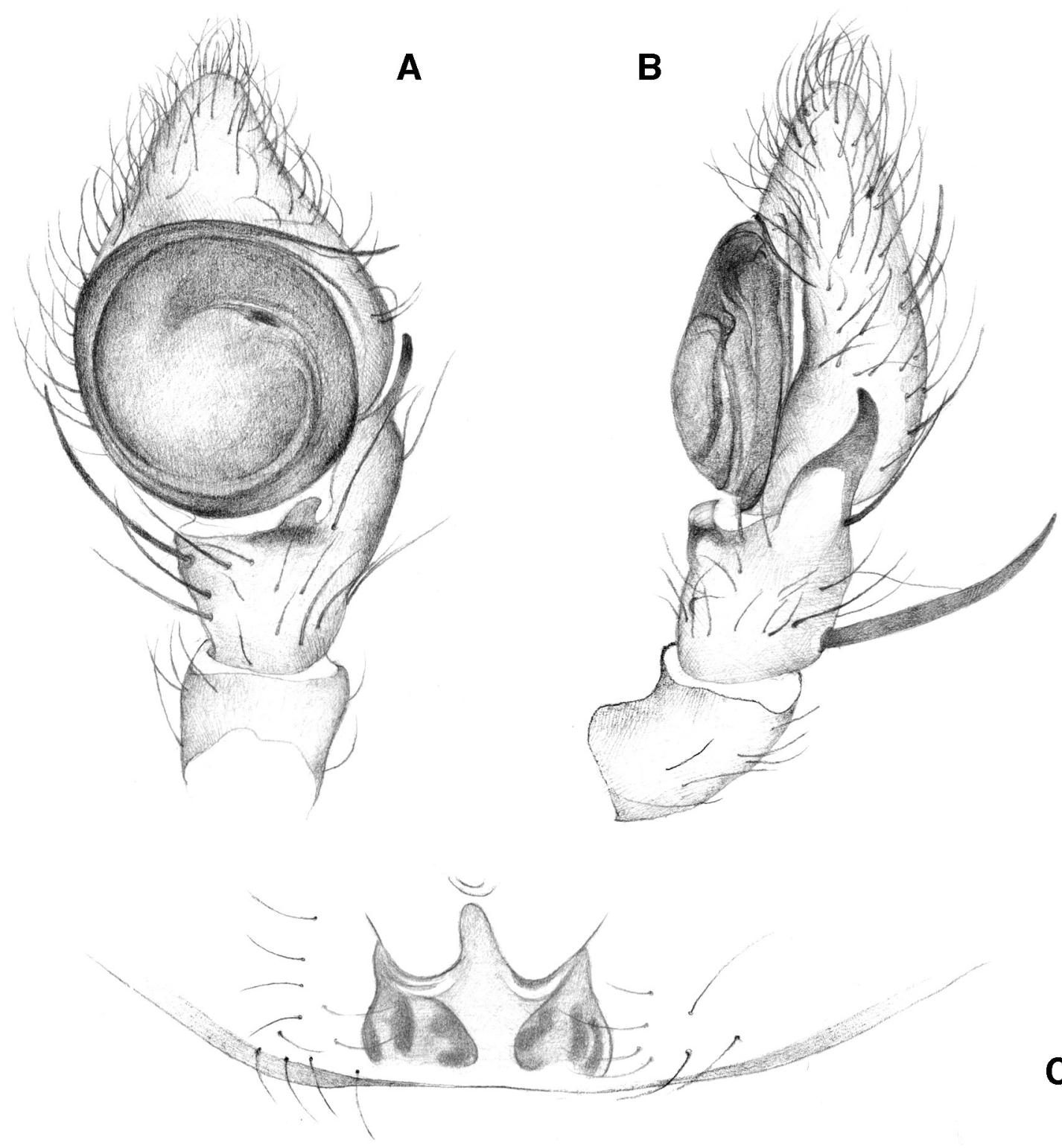

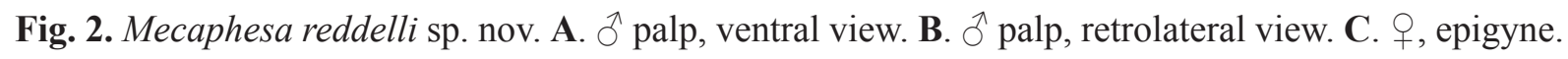




\section{Female allotype}

Total Length. 3.61; prosoma length: 1.76 , width: 1.75 , height: 0.45 ; chelicerae: 0.56 ; opisthosoma length: 2.37, width: 1.88, height: 1.28 .

Opisthosoma. Without long setae as in male.

Colour. Prosoma: cephalic region (clypeus and eye area) white; thorax region light brown with median dorsal white area connected to cephalic region by means of white longitudinal stripes; prosoma border white. Two strong setae behind each PLE. Chelicerae, endites and sternum: light brown with whitish tinge. Labium: light brown. Legs: light brown with whitish tinge; distal borders of $\mathrm{Fe}, \mathrm{Pa}$ and Ti white. Opisthosoma: dorsum white with 4 pairs of black dots of which the central 4 largest (Fig. 9E); sides creamy white; venter whitish; spinnerets whitish.

Eyes. MOQ: $\mathrm{AW}=0.74 \mathrm{PW}, \mathrm{AW}=0.84 \mathrm{LAP}, \mathrm{Cl}=3.4 \mathrm{DAME}, \mathrm{DALE}=0.16$.

Legs. Measurements: I (7.29): Fe 2.29, Pa 1.01, Ti 1.71, Mt 1.46, Ta 0.82; II (7.13): Fe 2.29, Pa 0.97, Ti 1.59, Mt 1.46, Ta 0.82; III (3.52): Fe 1.11, Pa 0.54, Ti 0.72, Mt 0.66, Ta 0.49; IV (3.85): Fe 1.22, Pa 0.52, Ti 0.82, Mt 0.78, Ta 0.51. Spination: Fe I: d2pl2, Fe II: d2-3, Fe III-IV: d2; Ti I-II: d2v 2 pairs of 4 spines; Mt I-II: d2pl1rl1v2 pairs of 5 spines. Pa III \& IV without 2 dorsal spines as in male.

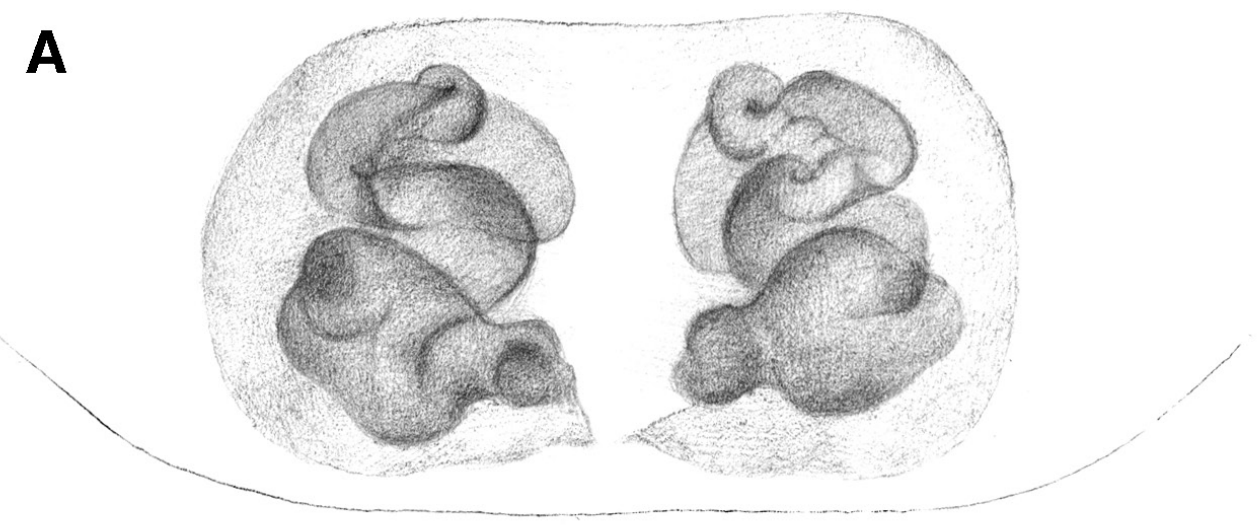

\section{B}

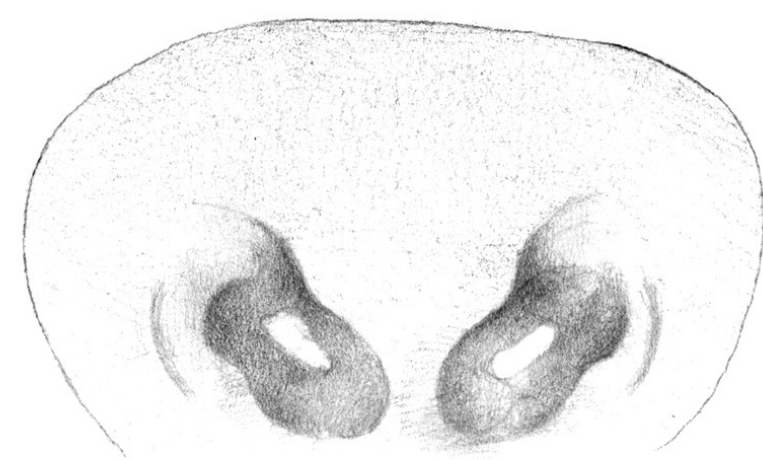

Fig. 3. - A. Mecaphesa inclusa (Banks, 1902), spermathecae. - B. M. reddelli sp. nov., spermathecae. 
EPIGYNe. Shape of epigyne cavity pentagonal with anterior borders slightly protruding; width of epigyne cavity: 0.17 (Fig. 2C); not very conspicuous small vulva compared to $M$. inclusa, small spermatheca with short copulatory ducts (Fig. 3B).

\section{Male Paratype}

Total LenGth. 3.02; prosoma length: 1.50 , width: 1.59 , height: 0.49 ; chelicerae: 0.43 ; opisthosoma length: 1.81 , width: 1.26 , height: 0.89 .

CoLour. Prosoma: As holotype but eye region not whitish.

Eyes. MOQ: $\mathrm{AW}=0.85 \mathrm{PW}, \mathrm{AW}=0.90 \mathrm{LAP}, \mathrm{Cl}=3.4 \mathrm{DAME}, \mathrm{DALE}=0.16$.

Legs. Measurements: I (8.43): Fe 2.59, Pa 0.94, Ti 2.04, Mt 1.88, Ta 0.98; II (7.91): Fe 2.39, Pa 0.90, Ti 1.92, Mt 1.76, Ta 0.94; III (3.70): Fe 1.15, Pa 0.52, Ti 0.83, Mt 0.70, Ta 0.50; IV (3.78): Fe 1.20, Pa 0.45, Ti 0.85, Mt 0.76, Ta 0.52. Spination: Fe I: d2pl2, Fe II: d2-3, Fe III: d2, Fe IV: d2; Pa I-II: d0, P III-IV: d2; Ti I-IV: d2.

\section{Colour variation in females}

The females from Isla Isabela (Volcán Alcedo and Volcán Darwin) are very similar in colour. Those of the northern islands (Pinta and Genovesa) differ from those of Isla Isabela in the following respects: the thoracic dorsal white area is flanked with a broad dark brown band in the Pinta female, while the Isla Genovesa female and juvenile female are in general more brownish.

\section{Distribution}

Santa Cruz, Volcán Alcedo and Darwin (Isla Isabela), Genovesa and Pinta. It was caught at different altitudes.

Genus Tmarus Simon, 1875

Tmarus galapagosensis sp. nov. urn:1sid:zoobank.org:act:04503524-81B7-48E2-B247-D10DAE2341EC

Figs $4 \mathrm{~A}-\mathrm{B}, 5 \mathrm{~A}-\mathrm{D}$

Tmarus stolzmanni - Keyserling, 1880: 138, pl. 3, fig. 74 (description đ). - Banks 1902: 62, pl. 1, fig. 5 (description đ). — Lubin 1983: 18; 1984: 240; 1985: 795. — Baert \& Maelfait 1986: 119, map 25; 2000: 244. — Baert, Maelfait \& Desender 1988: 50, 53; 1989: 22. — Baert, Maelfait, Hendrickx \& Desender 2008: 67, map 150.

\section{Diagnosis}

Males of $T$. galapagosensis can be recognized by the RTA with a curled tip and a dark curved hook at its base, and by the shape of the embolus which arises from the centre of the tegulum making three turns in retrolateral direction. Females differ from other Tmarus species by the rounded scapus-like plate without atrium (Fig. 5B, C), the subspherical spermathecae and the strongly curled copulatory ducts (Fig. 5D).

\section{Etymology}

The species name is derived from the geographic name Galápagos, as this species has a wide distribution throughout the archipelago. 


\section{Type material}

All type material deposited at the RBINS.

\section{Holotype}

§. ISLA SANTA CRUZ, vicinity of Cueva Andreas, arid zone, 20 m alt., 7 Apr. 1991, leg. L. Baert, J.-P. Maelfait \& K. Desender.

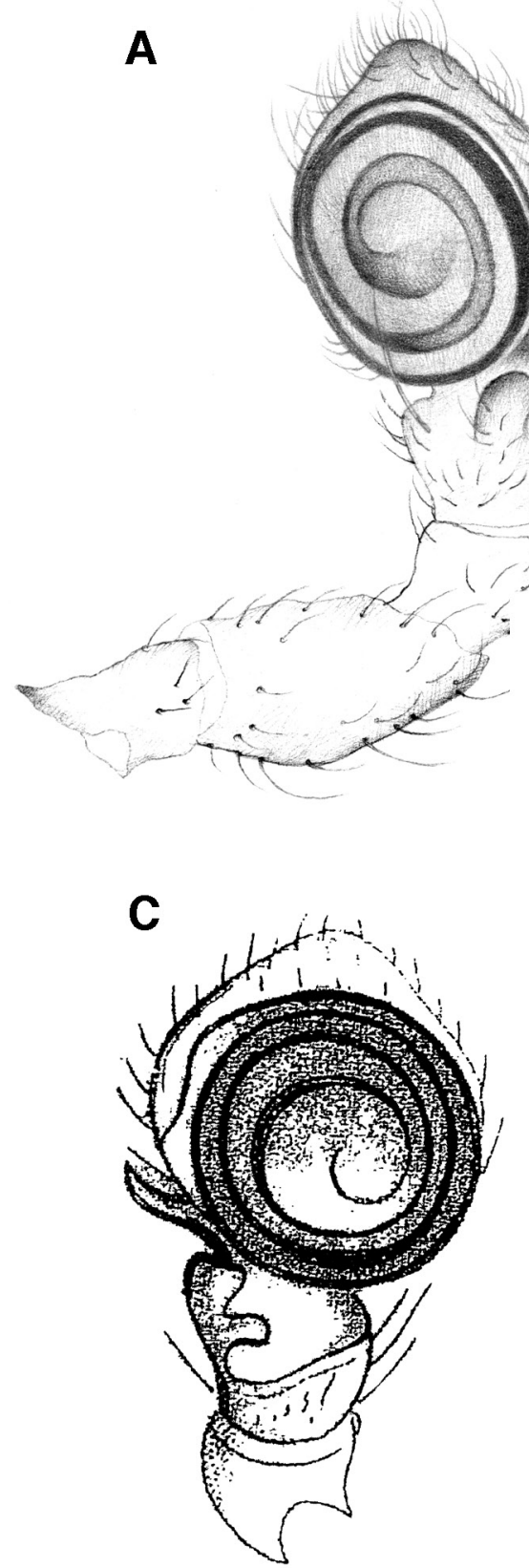

\section{B}
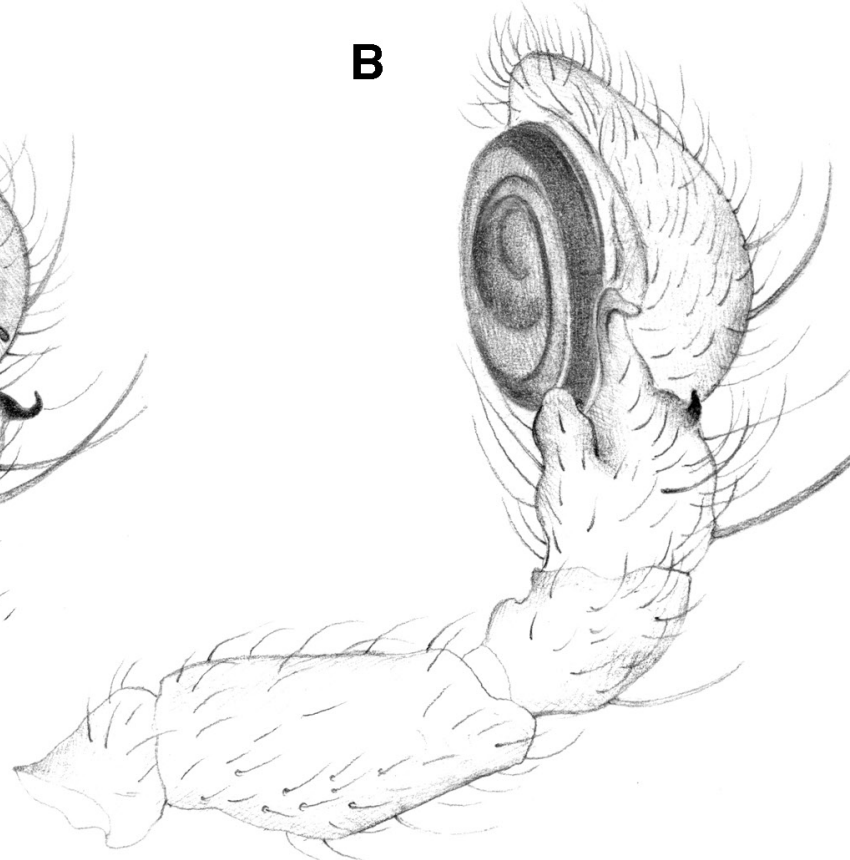

Fig. 4. - A-B. Tmarus galapagosensis sp. nov., §. A. Palp, ventral view. B. Palp, retrolateral view. C-D. Tmarus stolzmanni Keyserling, 1880, ô. C. Palp, ventral view after Keyserling (1880). D. Palp, ventral view after Banks (1902). 


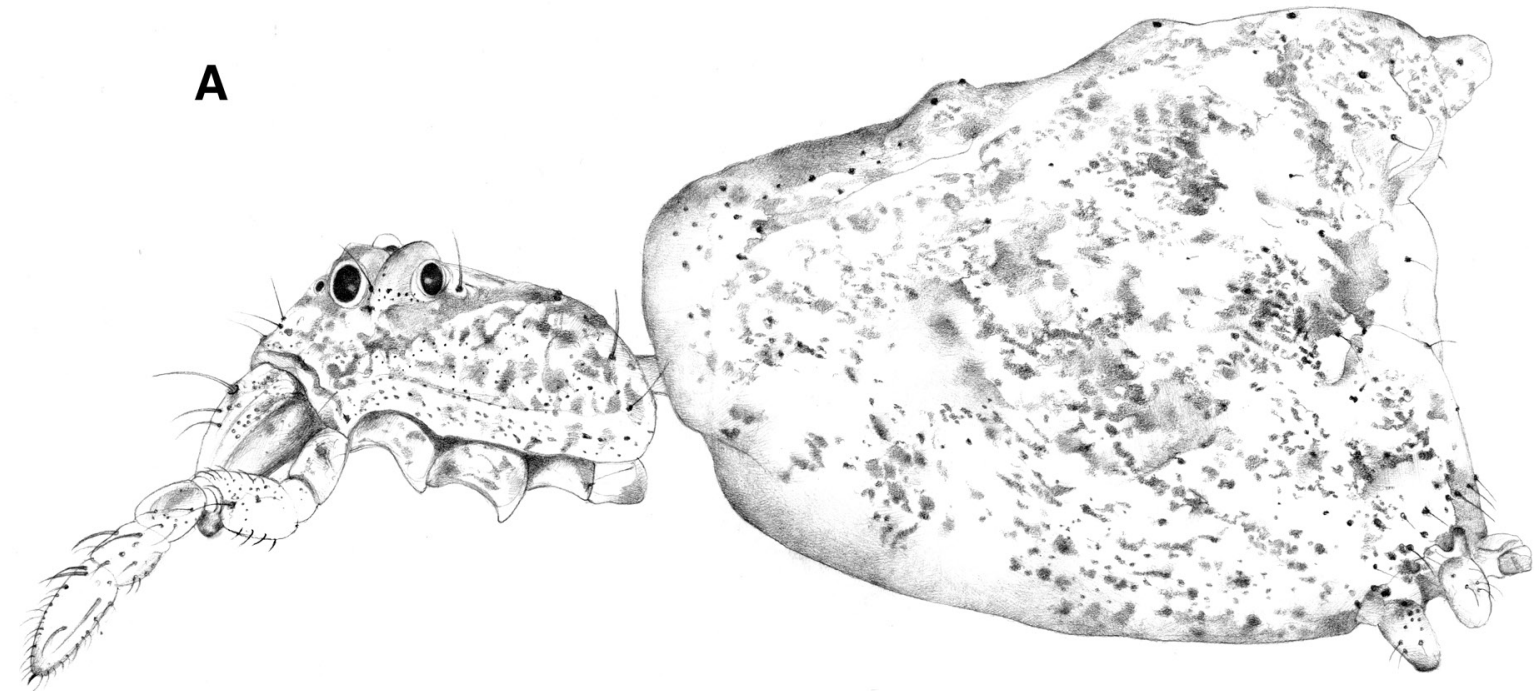

B

C
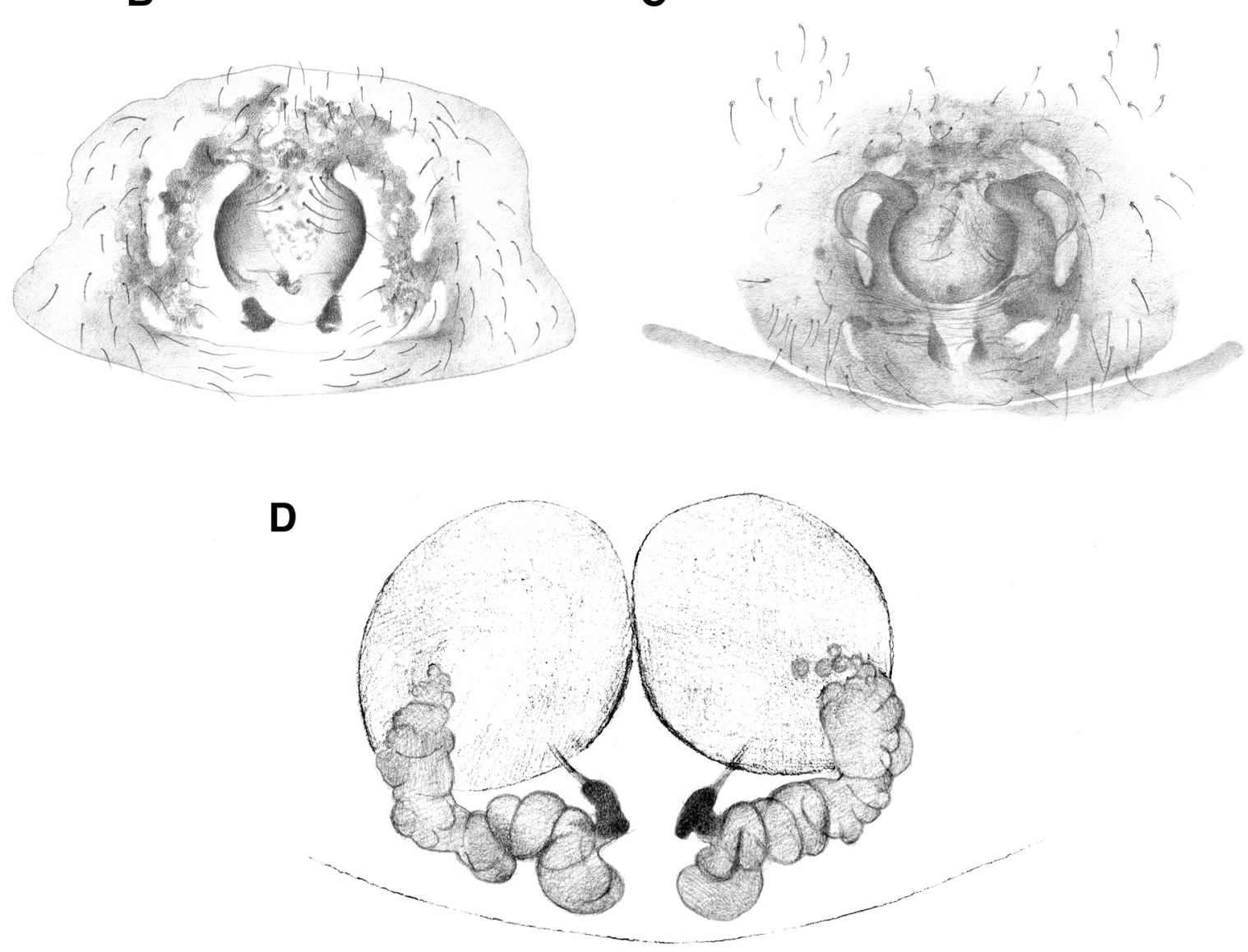

Fig. 5. Tmarus galapagosensis sp. nov., q. A. Lateral view. B-C. Epigyne. D. Spermathecae. 
Allotype

, ISLA FERNANDINA, Punta Espinosa, 24 Mar. 1988, leg. L. Baert, J.-P. Maelfait \& K. Desender.

\section{Paratypes}

ISLA MARCHENA: 1 §ึ, Playa Negra, Bursera forest, 5 m alt., 10 Mar. 1988, leg. L. Baert, J.-P.

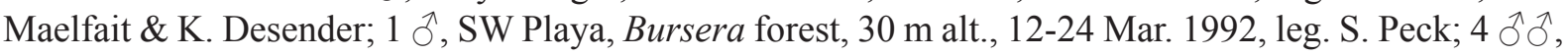
4 우, 3 juv., S-slope near beach camp, 5-10 m alt., night catch in Croton vegetation, 26 Jan. 1977, leg. W.G. Reeder.

ISLA ISABELA: 3 Ô, 1 †, 2 (q), Volcán Darwin, Beagle crater, night catch, 22 May 1980, leg. W.G. Reeder.

ISLA SANTA CRUZ: 1 \&, arid zone, Sep. 1964, leg. J. \& N. Leleup.

\section{Other material examined}

ISLA FERNANDINA: (q), Tail to Bursera Hills (West vegetation strip), 125 m alt., 27 Apr. 1975; , 3 juv., West vegetation strip (ash delta stream bed), $30 \mathrm{~m}$ alt., 11 Aug. 1977, leg. W.G. Reeder.

ISLA FLOREANA: 9 , Post Office Bay, arid zone, 20-30 Nov. 1925, ZMUN.

ISLA ISABELA: VOLCÁN SIERRA NEGRA: 0 ,,$~$, , 3 juv., road to the highlands (500 $\mathrm{m}$ from sea), 0-3 $\mathrm{m}$ alt., 11 Jan. 1978; ${ }^{\lambda}$,, , near Villamil (road to the highlands, $1 \mathrm{~km}$ from sea), 10-15 m alt., 11 Aug. 1978, (eg. W.G. Reeder. VOLCÁN ALCEDO: low arid zone, 5 m alt., new trail, 26 Oct.-2 Nov. 2001, leg. L. Roque; (đ), open Palo Santo wood, along old trail, Bursera vegetation, 200 m alt., 2-4 Apr. 1996,

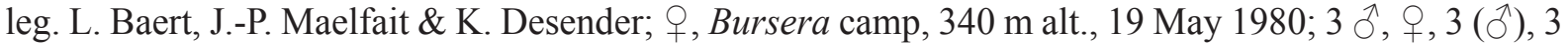

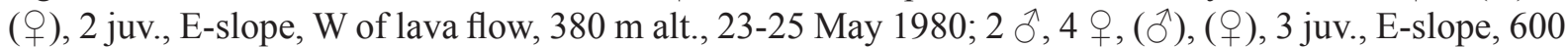
m alt., 24 May 1980, leg. W.G. Reeder. VOLCÁN DARWIN: (さ), Tagus Cove trail, 0-20 m alt., 2 May 1975. BEAGLE CRATER: $2 \AA \hat{\jmath}, 3$ juv., lava field between Beagle crater and volcano, 40-50 m alt., 22

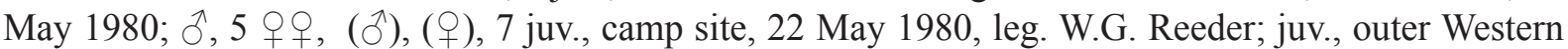
crater flank, Bursera vegetation, 20 m alt., 22 Feb. 1982, leg. L. Baert \& J.-P. Maelfait. VOLCÁN

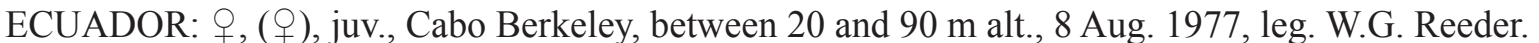

ISLA MARCHENA: ㅇ, 2 (우), SW slope beach camp area, 10-20 m alt., 30 Jan. 1977; 2 juv., South playa camp, $10 \mathrm{~m}$ of new lava flow, 16-20 m alt., 1 Feb. 1977; juv., near Barranco fumaroles, 160-190 m

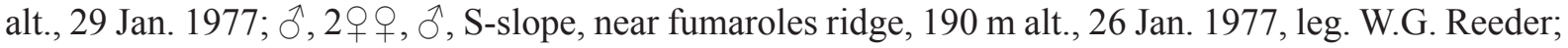
Punta Espejo, Bursera vegetation, 5 m alt., 11-24 Mar. 1992; đo, (ð), 2 juv. Playa Negra, steppe forest at $30 \mathrm{~m}$ alt., 12-24 Mar. 1992, leg. S. Peck.

ISLA PINTA: 3 ô, 2 , juv. 1 km NE of South Playa, 17-22 Jan. 1977, leg. W.G. Reeder; transition zone, $200 \mathrm{~m}$ alt., 14-22 Mar. 1992, leg. S. Peck.

ISLA PINZON: đ̂, 55-70 m alt., 2 Feb. 1975; đ, old crater camp, 320 m alt., 5 Feb. 1979, leg. W.G. Reeder; (ふ), Opuntia field near crater, 300 m alt., 25 Jan. 2010, leg. F. Hendrickx.

ISLA SANTIAGO: juv., Caleta Bucanero, Coldenia vegetation, 30 m alt., 9 Apr. 1982; 2 juv., Cerro Cowan, $260 \mathrm{~m}$ alt., 7 Apr. 1982, leg. L. Baert \& J.-P. Maelfait; $\widehat{\jmath}$, juv., Caleta Bucanero, $25 \mathrm{~m}$ alt., 10 Sep. 1975; (ठ), juv., Caleta Bucanero, lava ridge, 40-50 m alt., 19 Apr. 1975; đ̂, Crater area, 820$850 \mathrm{~m}$ alt., 14 Sep. 1975, leg. W.G. Reeder; §ึ, E-slope, $160 \mathrm{~m}$ alt., 16 Apr. 1964, CAS; (ð), juv., Los Guayabillos, 300 m alt., 14-16 May 1982, CDRS; ô, 2 + , Los Guayabillos, 300 m alt., 6-7 Apr. 1982, CDRS.

ISLA SANTA CRUZ: $\hat{\jmath}$, $q$, Academy Bay, 17.Oct.1969 (leg. S. Riechert).

ISLA SANTA FE: + , camp area, 5-10 m alt., 23 Jan. 1979, leg. W.G. Reeder; 2 juv. Highland, $100 \mathrm{~m}$ alt., 11-24 Mar. 1996, leg. S. Peck; (P), Highland, 150 m alt., 24 Apr. 1991, leg. L. Baert, J.-P. Maelfait \& K. Desender.

ISLA WOLF: juv., 2 Feb. 2002, CDRS. 
Material is deposited either at the RBINS (collections made by L. Baert et al., F. Hendrickx and S. \& J. Peck), TMM (collections made by W.G. Reeder and S. Riechert), CDRS (collections made by L. Roque and collaborators), CAS or ZMUN.

\section{Cited in the literature}

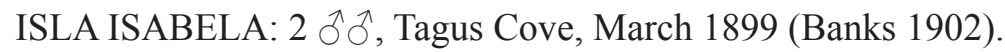

ISLA FLOREANA: juv., 29 Oct. \& 20-30 Nov. 1925 (Banks 1930).

ISLA SANTIAGO: numerous specimens, Los Guyabillos, 300 m alt. (Lubin 1983, 1984, 1985).

\section{Description}

\section{Male holotype}

Total Length. 3.49; prosoma length: 1.35 , width: 1.27 , height: 0.68 ; opisthosoma length: 2.03 , width: 1.07, height: 0.93 ; clypeus: 0.29 ; chelicerae: 0.49 .

Opisthosoma. Egg-shaped with small caudo-dorsal, sharp backwards-directed conical hump.

Colour. Prosoma: basic colour brown with white striae (darker than in female); MOQ and clypeus white connected to each other by a white stripe, eye tubercles with LE white encircled, slightly sloping clypeus bordered by a white stripe; dorsum creamy bordered by a white triangle, with some short and long spines. Clypeus with 5 spines ( 2 at border just above chelicerae and 1 centrally halfway). Chelicerae white with central creamy brown area, 2 long proximal spines and a row of 4 short spines along inner edge. Labium, endites and sternum creamy brown. Palp creamy with white stains, cymbium white. Legs: yellowish with few white and brownish stains. Opisthosoma: dorsum white, sides in apical half dusty, in caudal half white; venter creamy brown bordered by a white band; spinnerets white with brown spots.

Eyes. MOQ: $\mathrm{AW}=0.66 \mathrm{PW} ; \mathrm{AW}=0.66 \mathrm{LAP} ; \mathrm{Cl}=7.25 \mathrm{DAME} ; \mathrm{DAME}=0.04 \mathrm{DALE}=0.14$.

LeGs. Measurements: I (7.56): Fe 2.23, Pa 0.78, Ti 1.84, Mt 1.81, Ta 0.90; II (6.91): Fe 2.00, Pa 0.70, Ti 1.73, Mt 1.61, Ta 0.87; III (3.42): Fe 0.97, Pa 0.41, Ti 0.87, Mt 0.64, Ta 0.53; IV (3.32): Fe 1.07, Pa 0.41, Ti 0.72, Mt 0.58, Ta 0.54. Spination: Fe I: 2d5pl2rl, Fe II: 3d3pl1rl, Fe III: 2d1pl, Fe IV: 2d; Ti I: 2d3pl3rl2-2v, Ti II: 2d3pl3rl2-2v, Ti III: 2d, Ti IV: 2d; Mt I: 1rl 2-1-1v, Mt II: 1rl2-2v. Mt and Ta I-IV with distal row of 3 trichobotria.

PaLp. (Fig. 4A, B) Cymbium with 5 spines (2 prolateral, 1 central and 2 in retrolateral position). Tibia with 1 dark hook, 1 spine and 2 trichobotria in retrolateral position, 3 dorsal trichobotria and 2 spines in prolateral position; RTA with curled tip and dark curled hook at base; broad lobe-like VTA. Embolus arising centrally of tegulum, making three turns in retrolateral direction. Cymbium $=0.49$.

\section{Female allotype}

Total Length. 5.14; prosoma length: 1.74 , width: 1.59 , height: 0.75 ; opisthosoma length: 3.33 , width: 1.98, height: 1.92 ; clypeus: 0.35 ; chelicerae: 0.66 .

OpISTHOSOMA. Egg-shaped with conspicuous caudo-dorsal blunt, backwards-directed conical hump (Fig. $5 \mathrm{~A})$.

Colour. Whiter than male. Prosoma: white with faint brown striae; clypeus white, slightly sloping. Chelicerae, labium, endites, sternum and pedipalp: white with brown stains. Legs: yellow sparsely mottled with brown dots. Opisthosoma: dorsum and sides white, sparsely mottled with creamy brown stains; venter creamy brown band; spinnerets white with brown spots. 
Eyes. MOQ: $\mathrm{AW}=0.63 \mathrm{PW}$; $\mathrm{AW}=0.71 \mathrm{LAP} ; \mathrm{Cl}=5.8 \mathrm{DAME}$; DAME $=0.06$, DALE $=0.17$.

Legs. Measurements: I (7.45): Fe 2.29, Pa 0.87, Ti 1.75, Mt 1.61, Ta 0.93; II (7.01): Fe 2.12, Pa 0.85, Ti 1.61, Mt 1.50, Ta 0.93; III (4.16): Fe 1.17, Pa 0.58, Ti 1.01, Mt 0.76, Ta 0.64; IV (4.23): Fe 1.38, Pa 0.54, Ti 0.91, Mt 0.76, Ta 0.64. Spination: Fe I: 1d5pl1rl, Fe II: 2-3pl1rl, Fe III: 2d2pl; Ti I: 2d2pl2rl21-2v, Ti II: 2d2pl2rl2-1v, Ti III: 2d1v; Mt I: 2-2-1-1-2-2v, Mt II: 2-2-2v. Mt and Ta I-IV with distal row of 3 trichobotria.

EpIGYNE. A rounded scapus-like plate (Fig. 5 B-C). Two big, nearly spherical spermathecae and strongly curled long copulatory ducts; fertilisation ducts short (Fig. 5D), length of scapus: 0.35 .

\section{Biology}

Ant-eating nocturnal habit (Lubin 1983). Highly cryptic species, perfectly blending with the background of dry twigs covered with lichens, on which it sits during daytime. The pronounced abdominal dorsal hump gives the spider the appearance of a small protuberance or leaf scar on a twig (Lubin 1983).

Family Philodromidae Thorell, 1870

Genus Apollophanes O.P.-Cambridge, 1898

Apollophanes fitzroyi sp. nov. urn:Isid:zoobank.org:act:E94740CB-AED0-4D93-BEAC-0048BCDF8080

Figs $6 \mathrm{~A}-\mathrm{C}, 7 \mathrm{~A}-\mathrm{B}$

\section{Diagnosis}

Males of A. fitzroyi are recognized by the palp with RTA and VTA fused at base, the latter excavated, and by the short embolus arising at the distal end of the tegulum. Females are characterized by the epigyne with ovoid spermathecae provided with a prominent apical spermathecal organ.

\section{Etymology}

The species is named after Captain Fitzroy, commander of HMS Beagle, who made accurate navigational charts of the archipelago and took Charles Darwin to the islands in 1835.

\section{Type material}

\section{Holotype}

§, ISLA SANTIAGO, Playa Espumila, Arid zone, 3-9 Jun. 1991 (pan trap), leg. J. Heraty.

\section{Allotype}

, ISLA NORTH SEYMOUR, Bursera litter, 16 Oct. 1975, leg. W.G. Reeder.

\section{Paratypes}

ISLA SANTA CRUZ: $\widehat{\jmath}, 15 \mathrm{~km}$ north of Santa Rosa, alt. 140 m, arid zone forest, 1-30 Apr. 1992 (flying interception trap), leg. S. Peck; 1 đ, Cerro Colorado, alt. 10 m, 11 Mar. 1975, leg. W.G. Reeder. ISLA FERNANDINA: §̂, Cerro Verde, alt. 170 m, 9 May 1991 (night catch), leg. L. Baert, J.-P. Maelfait \& K. Desender.

\section{Juveniles}

ISLA SANTA FÉ: + , in detritus along coastline, 15 May 1975, leg. H. Franz.

ISLA SANTIAGO: $\widehat{\text { O}}$, alt. 580 m, transition wood, 8 Apr. 1982, leg. L. Baert \& J.-P. Maelfait. 


\section{Description}

\section{Male holotype}

Total Length. 4.63; prosoma length: 1.98 , width: 1.92, height: 0.87 .

CoLour. Prosoma: Orange brown, strongly speckled with small black spots along sides, with sparse short setae, hairy (white hairs); chelicerae creamy, strongly speckled; labium, endites \& sternum creamy, very sparsely speckled. Legs: Creamy strongly speckled with black. Pedipalp creamy. Opisthosoma: creamy with greyish sides and median greyish lanceolate heart mark, many short setae, venter creamy; anal tubercle surrounded by many setae.

Eyes. MOQ: $\mathrm{AW}=0.73 \mathrm{PW}, \mathrm{AW}=0.89 \mathrm{LAP}, \mathrm{Cl}=2.3 \mathrm{DAME}$.

Legs. Measurements: I (9.47): Fe 2.78, Pa 1.10, Ti 2.35, Mt 2.10, Ta 1.14; II (11.65): Fe 3.29, Pa 1.22, Ti 2.94, Mt 2.75, Ta 1.45; III (8.47): Fe 2.63, Pa 0.90, Ti 2.00, Mt 2.00, Ta 0.94; IV (8.39): Fe 2.63, Pa 0.86, Ti 2.00, Mt 2.00, Ta 0.90. Length of cymbium: 0.70. Spination: Fe I: 3d2pl3rl, Fe II: 3d3pl3rl, Fe III: 3d2pl1rl, Fe IV: 3d2distal rl; Ti I-IV: 1d2pl2rl2-2-2v; 3pl3rl2-2v.

PALP. (Fig. 6A-C) Cymbium long oval, with a retrolateral and prolateral spine. Tibia with 1 dorsal and 1 prolateral spine; VTA and RTA fused at base, VTA excavated (Fig. 6C). Embolus short, arising at distal end of tegulum. Femur with 3 dorsal spines of which 2 at distal end.

\section{Female allotype}

Total Length. 5.40; prosoma length: 2.59, width: 2.51, height: 0.72 .
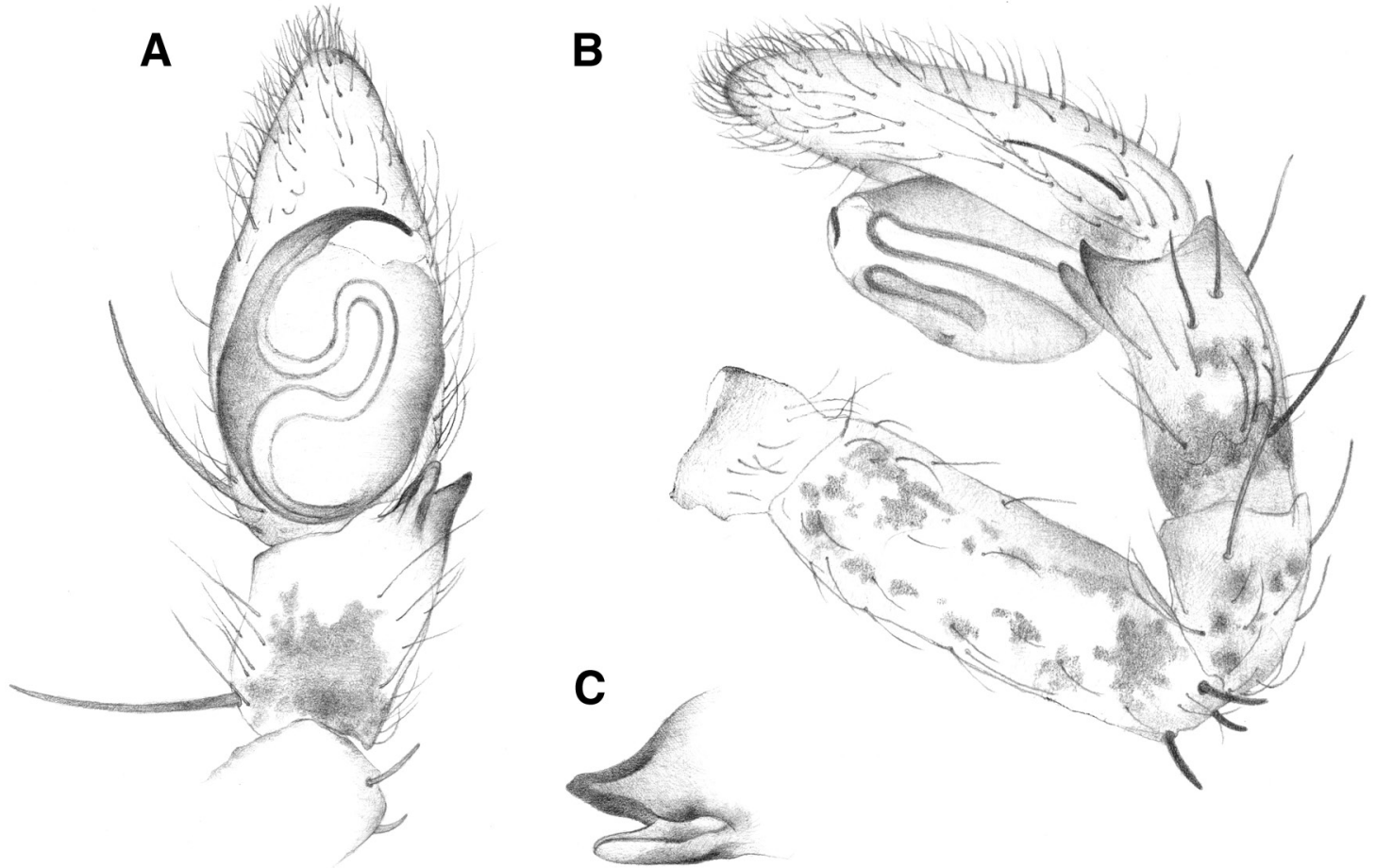

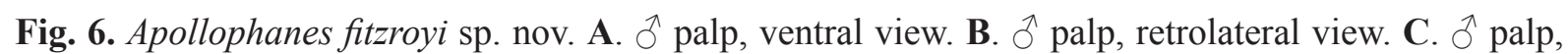
tibial apophysis. 
Colour. Prosoma: As in male, but speckled with brown along sides; chelicerae creamy, strongly speckled; labium, endites \& sternum creamy, very sparsely speckled. Legs: Creamy with fewer black spots. Opisthosoma: whitish with creamy sides and median creamy lanceolate heart mark, many short setae, venter creamy; anal tubercle surrounded with many setae.

EYES. MOQ: $\mathrm{AW}=0.80 \mathrm{PW}, \mathrm{AW}=0.93 \mathrm{LAP}, \mathrm{Cl}=2.75$ DAME.

Legs. Measurements: I (10.04): Fe 2.98, Pa 1.37, Ti 2.47, Mt 2.08, Ta 1.14; II (10.76): Fe 3.61, Pa 1.56, Ti 2.94, Mt 2.43, Ta 1.22; III (9.22): Fe 2.90, Pa 1.22, Ti 2.24, Mt 1.88, Ta 0.98; IV (9.18): Fe 2.94, Pa 1.10, Ti 2.16, Mt 2.04, Ta 0.94 .

EpIGYNe. (Fig. 7) Medium septum with broad elongate copulatory openings (Fig. 7A), spermathecae ovoid with a prominent apically situated spermathecal organ (Fig. 7B).

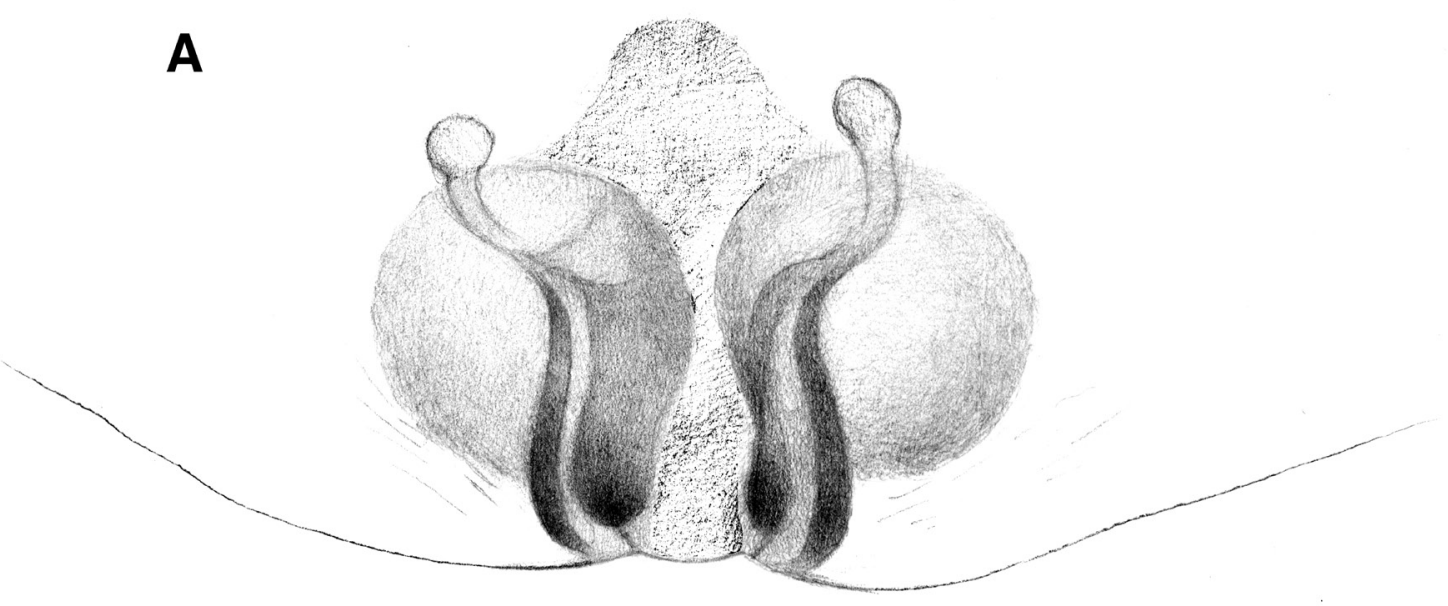

B

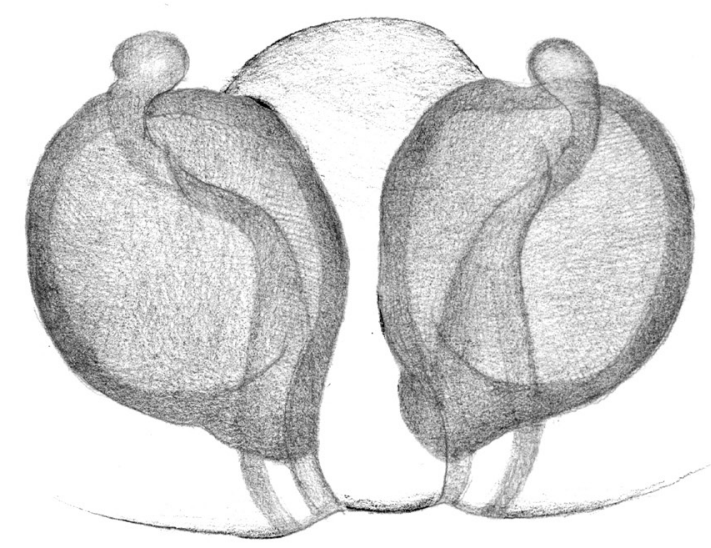

Fig. 7. Apollophanes fitzroyi sp. nov. A. + , epigyne (ventral view). B. Spermathecae (dorsal view). 


\section{Distribution}

The species seems to be confined to the central islands of Santa Cruz, Seymour Norte, Santa Fé and Santiago. It has been found on Santa Cruz in the lower arid zone (5-10 m alt.) and in the transition forest zone (110-250 $\mathrm{m}$ alt.), on Santiago in the transition forest at a higher elevation (580 $\mathrm{m}$ alt.).

\section{Remarks}

The closely fused VTA and RTA of the male palpal tibia, the absence of a membranous area at the base of the embolus (\# of Thanatus C. L. Koch, 1837), the equidistant posterior eyes (\# of Tibellus Simon, 1875) and the elongated copulatory openings located at sides of septum (epigynal slits) reaching the epigynal fold in the female and the vulval conformation (spherical spermatheca and apical small spermatecal organ) observed in this galapagoan species, show it clearly belongs to the genus Apollophanes (Dondale \& Redner 1975; Muster 2009). It resembles A. punctipes (O.P. Cambridge, 1891) most closely, but a thorough examination of the male and female type material of this species clearly showed the morphological differences between both species.

Apollophanes (?) lonesomegeorgei sp. nov.

urn:lsid:zoobank.org:act:496BAC9E-DFF4-4E85-A5DE-D884CADED44F

Figs $8 \mathrm{~A}-\mathrm{B}, 10 \mathrm{~A}-\mathrm{B}$

\section{Diagnosis}

Males of $A$. (?) lonesomegeorgei are recognized by the palp with compressed VTA and RTA, strongly curled embolus with filiform tip pointing backwards and opisthosoma covered with many white and a few dark scale-like hairs.
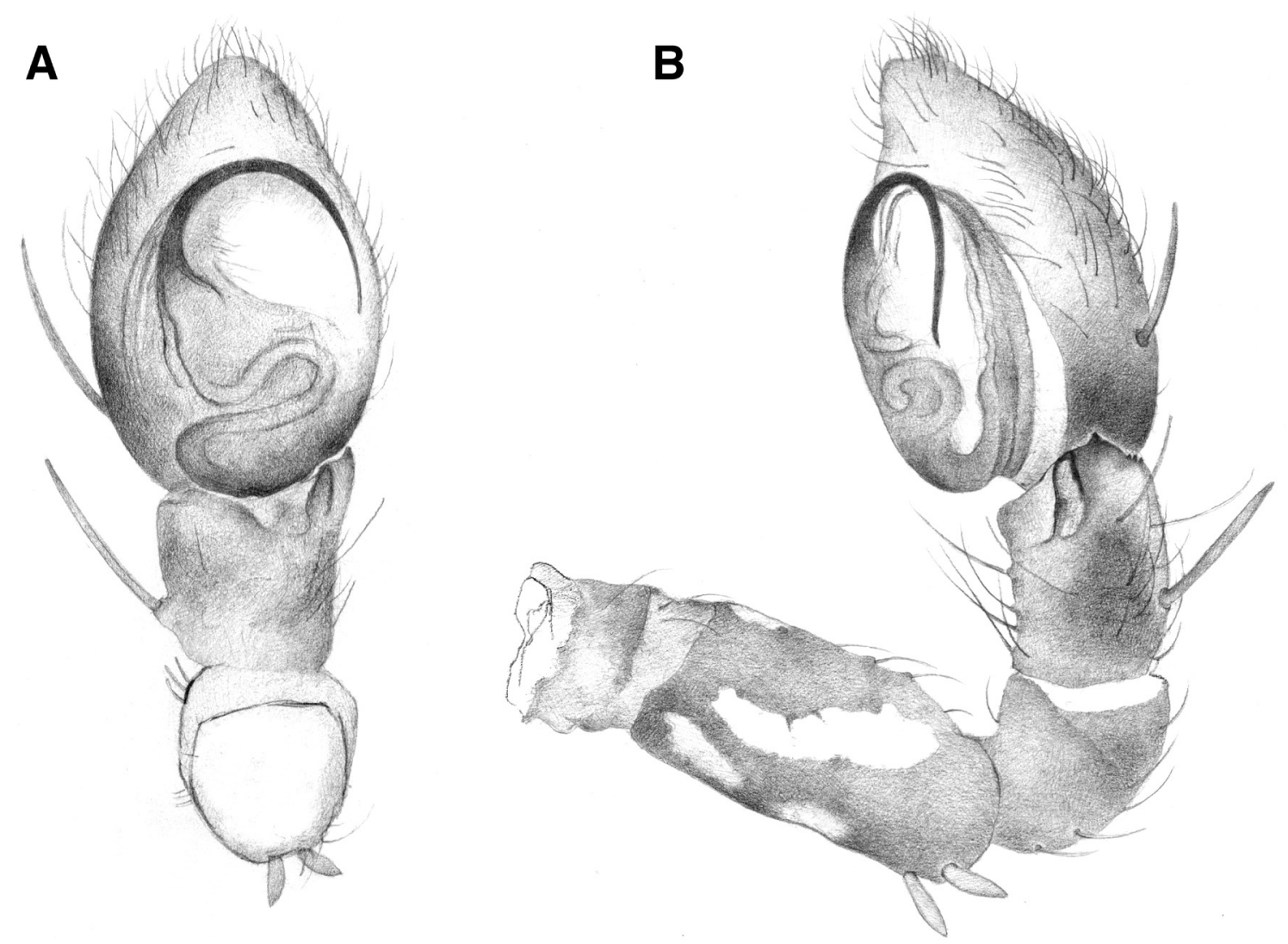

Fig. 8. Apollophanes (?) lonesomegeorgei sp. nov. A. đ̊ palp, ventral view. B. đ̊ palp, retrolateral view. 


\section{Etymology}

The species is named after "Lonesome George" the last Isla Pinta tortoise (Chelonoidis abingdonii (Günther, 1877)) survivor which died on June $24^{\text {th }}$ of 2012 , emphasizing in this way the uniqueness of this spider specimen as explained in the discussion above.

\section{Type material}

\section{Holotype}

đ, ISLA WOLF, alt. 75 m, Croton forest, 11 May 1996 (pitfall trap), leg. S. Peck.
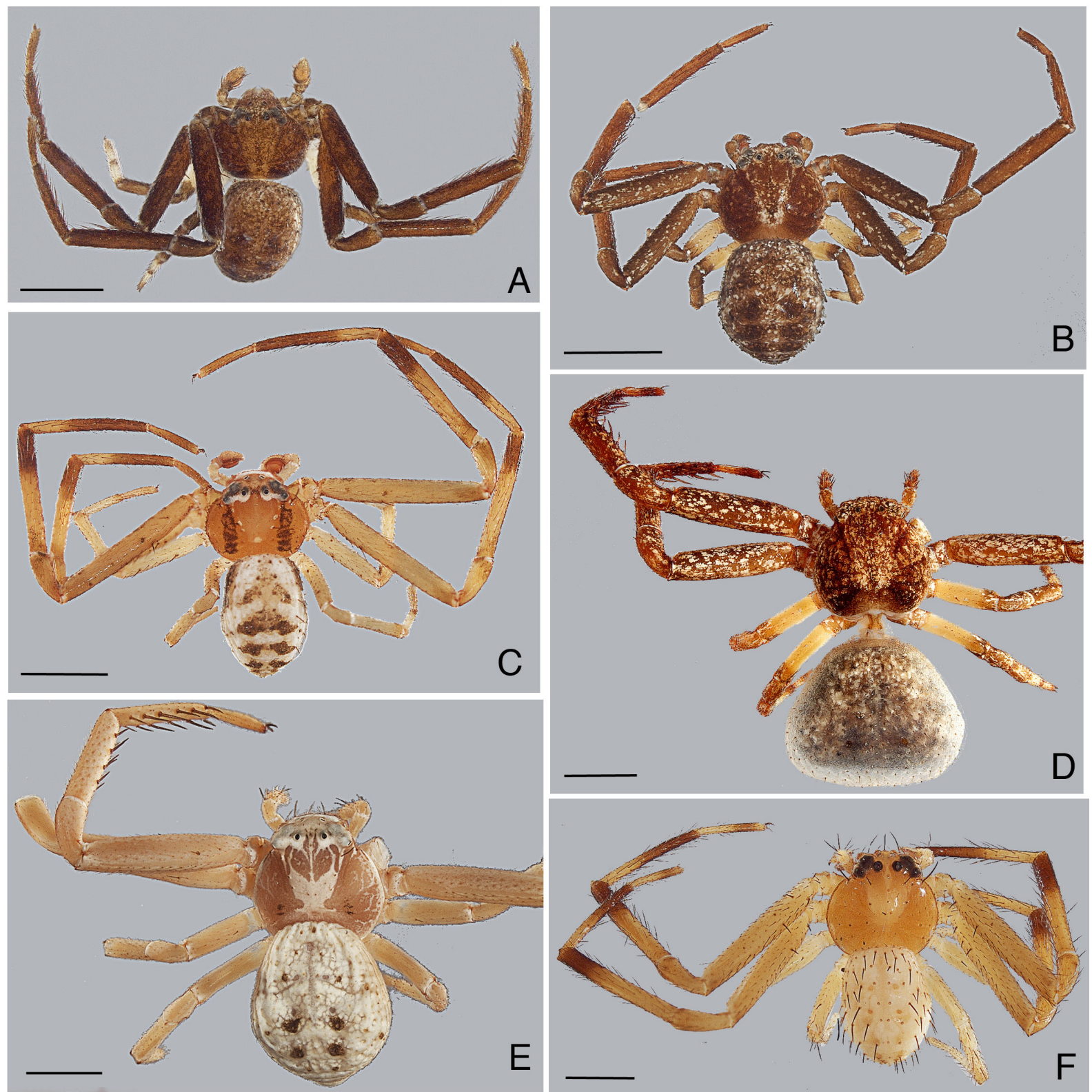

Fig. 9. Habitus. - A-D. Mecaphesa inclusa (Banks, 1902). A. đ̊ colour type A. B. ô colour type B. C. đ̃ colour type C. D. $q$ colour type C. - E-F. Mecaphesa reddelli sp. nov. E. $q$ of Volcán Alcedo (Isla Isabela). F. $\widehat{\jmath}$ of Volcán Alcedo (Isla Isabela). Scale bars: 1 mm. Photographs by Rudy Jocqué. 


\section{Description}

\section{Male}

Total LenGth. 3.92; prosoma length: 1.75 , width: 1.81 , height: 0.62 , clypeus: 0.31 ; opisthosoma length: 1.75 , width: 1.65 .

BoDy. Prosoma: yellow dorsal band covered with white scale-like hairs, dark brown sides covered with black scale-like hairs; bordered with white scale-like hairs; chelicerae with many short setae, proximal part creamy, distal part dark; labium creamy grey; endites whitish gray; sternum creamy slightly suffused with grey. Legs I \& II: whitish yellow; Fe, Pa \& Ti ventrally dark (blackish); Ta and distal end of Mt with dense scopulae; Ta with accessory claw. Legs III \& IV lacking. Opisthosoma: white, covered with white scale-like hairs, black apical heart mark covered with black scale-like hairs, sides mottled with dark stains, venter creamy, spinnerets light. Prosoma and opisthosoma more or less densely covered with scale-like hairs. Frontal face of chelicerae covered with many short spines.

EYes. AME: $0.08<$ ALE: 0.10; MOQ: AW = 0.73 PW; AW = 0.69 LAP; $\mathrm{Cl}=3.4$ DAME. AME smaller than ALE, anterior eye-row strongly recurved; PME closer to PLE (PM-PM: 0.214, PL-PM: 0.135); AME closer to ALE (AM-AM: 0.097, AL-AM: 0.078).

Legs. Measurements: I (7.07): Fe: 2.12, Pa: 0.84, Ti: 1.68, Mt: 1.49, Ta :0.94; II (8.44): Fe: 2.54, Pa: 0.90, Ti: 2.08, Mt: 1.86, Ta: 1.06. Length of cymbium: 0.54. Spination: Fe I: 2d2pl, Fe II: 2d, Ti I: 1-2v, Ti II: 2-2-2v; Mt I: 2-2v1pl1rl, Mt II: 2-2v1pl1rl. Only Mt (I \& II) with retro- and prolateral spine.

Palp. (Fig. 8) Cymbium short oval with 1 prolateral and 1 retrolateral position spine; tegulum without apophysis and distinctive fold at the point of origin of the embolus, with strongly curled embolus as in Titanebo (Muster, 2009; fig. 3). Tibia with 2 prolateral spines, 2 dorsal spines and 2 dorsal trichobotria; cusplike VTA and flat RTA apparently compressed together; RTA with short pointed tip and 3 small denticles in the upper part of it's distal edge. Pa with two short dorsal spines. Fe with two distal short thick setae. Embolus arising at prolateral side of tegulum.

Female

Unknown.
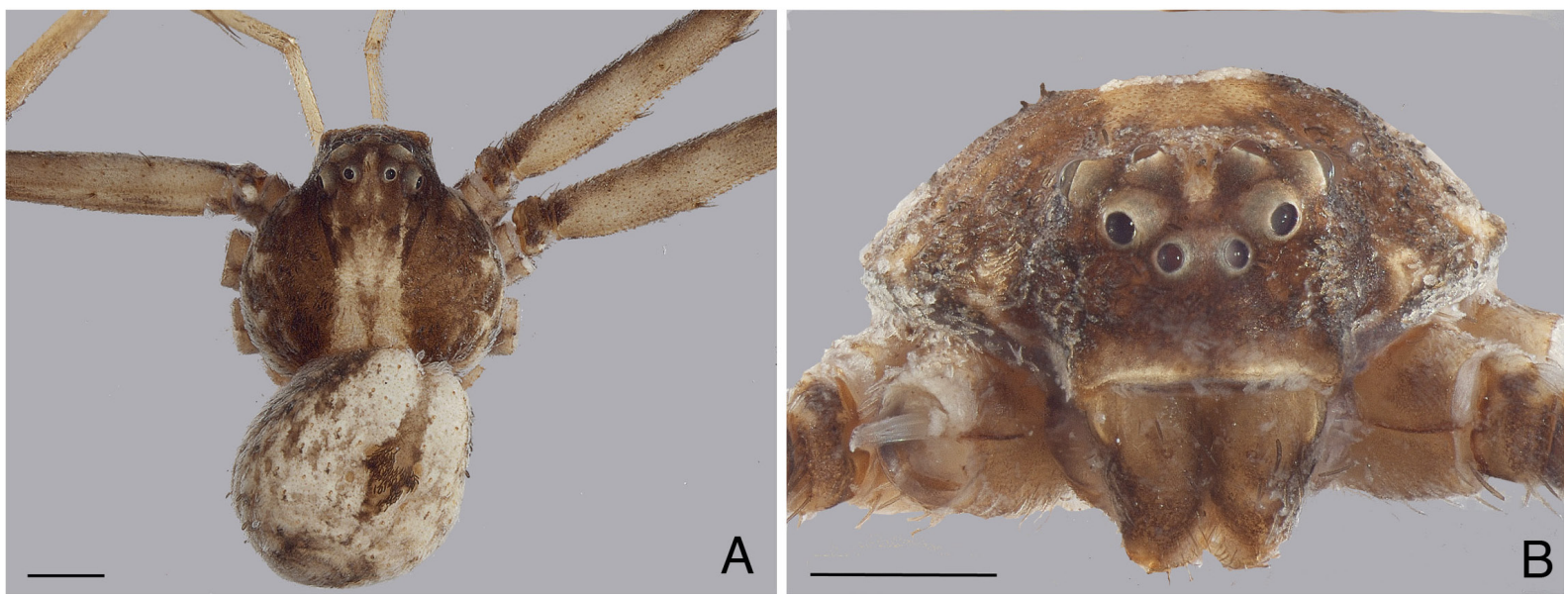

Fig. 10. Apollophanes (?) lonesomegeorgei sp. nov. A. đ̊ prosoma, dorsal view. B. ô prosoma, frontal view (AM and AL eyes). Scale bars: $0.5 \mathrm{~mm}$. Photographs by Rudy Jocqué. 


\section{Remarks}

This damaged specimen definitely belongs in the Philodromidae (presence of claw tufts) but cannot with certainty be placed in a known genus due to the number of deviating characters.

The principal contrasting characters are: AME smaller than ALE, anterior eye-row strongly recurved (in contrast to Ebo Keyserling, 1884, Titanebo Gertsch, 1933 and Halodromus Muster, 2009) (Fig. 10B); posterior eye-row procurved (Fig. 10A); prosoma slightly wider than long, covered with scale-like hairs (Fig. 10A); opisthosoma covered with many white and a few dark scale-like hairs; only metatarsi with retro- and prolateral spine (in contrast to Ebo and Titanebo); tibia of male palp with small apophysis (VTA and RTA apparently compressed), embolus strongly curled with filiform tip pointing backwards. For the time being I have placed it in Apollophanes, which appears to be the closest genus.

\section{Acknowledgements}

I am indebted to Frederick Hendrickx (2002 \& 2010) \& Wouter Dekoninck (2009 \& 2010) (Belgium), Stewart Peck \& John Heraty (Canada), Heinrich \& Irene Schatz (Austria), Sandra Abedrabbo, Sonja Sandovall, Germania Estevez, Lazaro Roque \& Henri Herrera (Ecuador) for assistance in the field. I received support from the Charles Darwin Research Station (CDRS) and the Parque Nacional de Galápagos (SPNG). Financial support was given by the Belgian State (now Belspo), FWO and Léopold III Fund.

Thanks go to James Reddell of the Texas Memorial Museum (University of Texas) for the loan of the spider collections made by W.G. Reeder, to Janet Beccaloni of the Natural History Museum of London for the loan of the type specimens of Apollophanes punctipes (Pickard-Cambridge, 1891) and to Adriano Kury of the Museu Nacional of Rio de Janeiro for the loan of the many Tmarus species present in the museum collection.

Special thanks go to Marylise Leclercq who made all the drawings and to Rudy Jocqué for the improvement of the English language and assistance with the photographs.

\section{References}

Baert L. \& Maelfait J.-P. 1986. A contribution to the knowledge of the spider fauna of Galápagos (Ecuador). Bulletin van het Koninklijk Belgisch Instituut voor Natuurwetenschappen, Entomologie 56: 93-123.

Baert L. \& Maelfait J.-P. 2000. Check list of the described spider species of the Galápagos archipelago (Araneae). Bulletin van het Koninklijk Belgisch Instituut voor Natuurwetenschappen, Entomologie 70: 43245.

Baert L., Maelfait J.-P. \& Desender K. 1988. Results of the Belgian 1986-expedition: Araneae, and provisional checklist of the spiders of the Galápagos archipelago. Bulletin van het Koninklijk Belgisch Instituut voor Natuurwetenschappen, Entomologie 58: 29-54.

Baert L., Maelfait J.-P. \& Desender K. 1989. Results of the Belgian 1988-expedition to the Galápagos islands: Araneae. Bulletin van het Koninklijk Belgisch Instituut voor Natuurwetenschappen, Entomologie 59: 5-22.

Baert L., Maelfait J.-P., Hendrickx F. \& Desender K. 2008. Distribution and habitat preference of the spiders (Araneae) of Galápagos. Bulletin van het Koninklijk Belgisch Instituut voor Natuurwetenschappen, Entomologie 78: 39-111.

Banks N. 1902. Papers from the Hopkins Stanford Galápagos Expedition. 1898-1899. VII. Entomological results (6), Arachnida by N. Banks and field notes by R.E. Snodgrass. Proceedings of the Washington Academy of Sciences 4: 49-86. 
Banks N. 1930. The Norwegian Zoological expedition to the Galápagos Islands, 1925, conducted by Alf Wollebaek. I. Arachnida. Nyt Magazin for Naturvidenskaberne 68: 271-278.

Dondale C.D. \& Redner J.H. 1975. Revision of the spider genus Apollophanes (Araneida : Thomisidae). The Canadian Entomologist 107 (11): 1175-1192. http://dx.doi.org/10.4039/Ent1071175-11

Keyserling E. 1880. Die Spinnen Amerikas, Laterigradae. Verlag von Bauer \& Raspe, Nürnberg.

Lehtinen P.T. 1993. Polynesian Thomisidae - a meeting of old and new world groups. Memoirs of the Queensland Museum 33 (2): 585-592.

Lubin Y. 1983. An ant-eating crab spider from the Galápagos. Noticias de Galápagos 37: 18-19.

Lubin Y. 1984. Changes in the native fauna of the Galápagos Islands following invasion by the little red fire ant, Wasmannia auropunctata. Biological Journal of the Linnean Society 21 (1-2): 229-242. http:// dx.doi.org/10.1111/j.1095-8312.1984.tb02064.x

Lubin Y. 1985. Studies on the little fire ant, Wasmannia auropunctata, in a Niño year. In: Robinson G. \& del Pino E.M. (eds) El Niño en las Islas Galápagos: El evento de 1982-1983, Fundación Charles Darwin: 473-793. Quito, Ecuador.

Mello-Leitão C. F. de 1929. Aphantochilidas e Thomisidas do Brasil. Archivos do Museu nacional do Rio de Janeiro 31: 9-359.

Mello-Leitão C. F. de 1941. Las arañas de Córdoba, La Rioja, Catamarca, Tucumán, Salta y Jujuy colectadas por los Profesores Birabén. Revista del Museo de La Plata (N.S., Zool.) 2: 99-198.

Mello-Leitão C. F. de 1942. Arañas del Chaco y Santiago del Estero. Revista del Museo de La Plata (N.S., Zool.) 2: 381-426.

Mello-Leitão C. F. de 1943. Catálogo das aranhas do Rio Grande do Sul. Archivos do Museu nacional do Rio de Janeiro 37: 147-245.

Mello-Leitão C. F. de 1944. Algumas aranhas da região amazônica. Boletim do Museu nacional do Rio de Janeiro (N.S., Zool.) 25: 1-12.

Mello-Leitão C. F. de 1949. Aranhas da Foz do Kuluene. Boletim do Museu nacional do Rio de Janeiro (N.S., Zool.) 92: 1-19.

Muster C. 2009. The Ebo-like running crab spiders in the Old World (Araneae, Philodromidae). ZooKeys 16: 47-73. http://dx.doi.org/10.3897/zookeys.16.230

Roth V.D. \& Craig P.R. 1970. Arachnida of the Galapagos islands (excluding Acarina). In: Leleup N. \& Leleup J. (eds) Mission zoologique belge aux Iles Galapagos et en Ecuador. Résultats scientifiques, deuxième partie: 107-124. Musée Royal de l'Afrique Centrale, Tervuren.

Manuscript received: 22 August 2012

Manuscript accepted: 20 March 2013

Published on: 2 May 2013

Topic editor: Rudy Jocqué

Desk editor: Kristiaan Hoedemakers

Printed versions of all papers are also deposited in the libraries of the institutes that are members of the EJT consortium: Muséum National d'Histoire Naturelle, Paris, France; National Botanic Garden of Belgium, Meise, Belgium; Royal Museum for Central Africa, Tervuren, Belgium; Natural History Museum, London, United Kingdom; Royal Belgian Institute of Natural Sciences, Brussels, Belgium; Natural History Museum of Denmark, Copenhagen, Denmark. 